\title{
Coral reefs as a source of climate-active aerosols
}

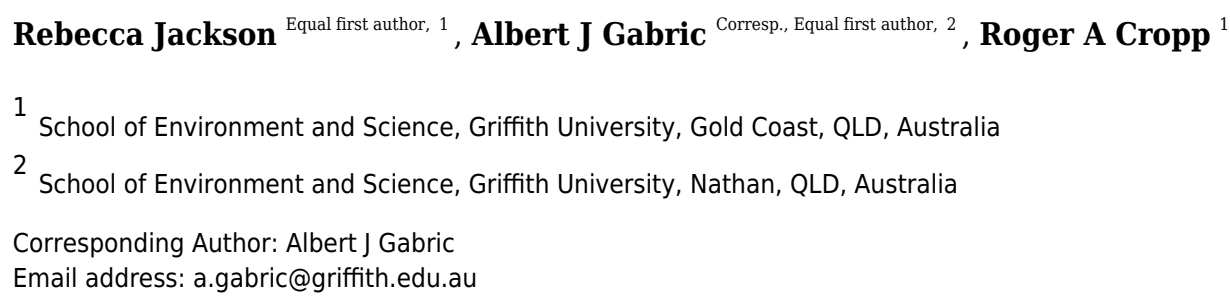

We review the evidence for bio-regulation by coral reefs of local climate through stressinduced emissions of aerosol precursors, such as dimethylsulfide. This is an issue that goes to the core of the coral ecosystem's ability to maintain homeostasis in the face of increasing climate change impacts and other anthropogenic pressures. We examine this through an analysis of data on aerosol emissions by corals of the Great Barrier Reef (GBR), Australia. We focus on the relationship with local stressors, such as surface irradiance levels and sea surface temperature, both before and after notable coral bleaching events. We conclude that coral reefs may be able to regulate their exposure to environmental stressors through modification of the optical properties of the atmosphere, however this ability may be impaired as climate change intensifies. 
1

2 "Coral Reefs as a Source of Climate-active Aerosols"

3

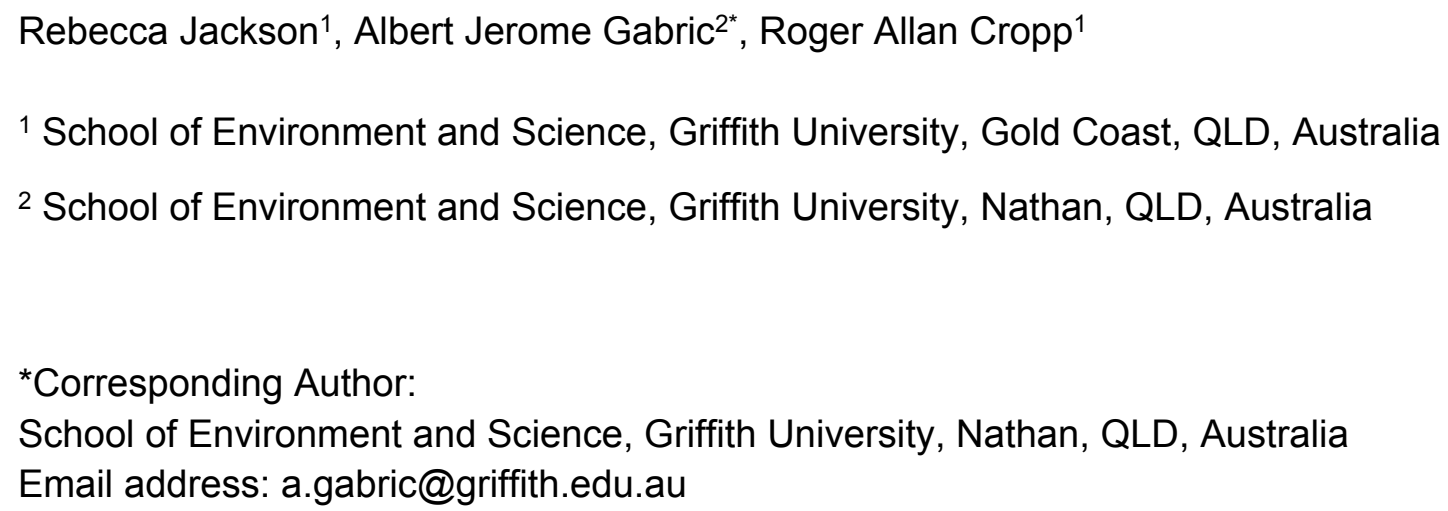

\section{Abstract} of the atmosphere, however this ability may be impaired as climate change intensifies.

\section{Introduction}

We review the evidence for bio-regulation by coral reefs of local climate through stress-induced emissions of aerosol precursors, such as dimethylsulfide. This is an issue that goes to the core of the coral ecosystem's ability to maintain homeostasis in the face of increasing climate change impacts and other anthropogenic pressures. We examine this through an analysis of data on aerosol emissions by corals of the Great Barrier Reef (GBR), Australia. We focus on the relationship with local stressors, such as surface irradiance levels and sea surface temperature, both before and after notable coral bleaching events. We conclude that coral reefs may be able to regulate their exposure to environmental stressors through modification of the optical properties

Coral reefs cover some 600,000 square kilometers of the earth's surface $(0.17 \%$ of the ocean surface), with coral ecosystems amongst the most diverse on the planet (Knowlton 2001). Coral reefs currently provide a range of ecological services including food and shelter for a variety of marine species, nutrient cycling, as well as income from tourism and fisheries for about 500 million 
people world-wide (Moberg and Folke 1999, Hoegh-Guldberg et al. 2007, Hoegh-Guldberg et al. 2017). The total economic value of direct and indirect services that corals provide is estimated to be in the billions to trillions of \$US per annum - the highest of all quantified biomes (Costanza et al. 2014). However, coral reefs globally have suffered long-term decline in abundance, diversity, and habitat structure due to overfishing and land-based pollution, with most reefs already degraded by the late $19^{\text {th }} \mathrm{C}$ (Pandolfi et al. 2003). Live coral cover has decreased significantly since baseline monitoring began in the late 1970s, anywhere from 46-93\%, depending on the region (Jackson 2008), causing many scientists to doubt their long term survival without the use of non-conventional interventions (Knowlton and Jackson 2008, Anthony et al. 2017).

On many reefs, reduced stocks of herbivorous fishes together with increased sediment and nutrient loading from land-based activities (Gabric and Bell 1993, Bell et al. 2014) have caused ecological regime shifts away from the original dominance by corals to a preponderance of fleshy seaweed (Hughes et al. 2007, Brodie et al. 2011). These regime shifts can occur suddenly (Bestelmeyer et al. 2011), and are often irreversible (Schmitt et al. 2019). In non-linear systems theory these alternate stable states are known as alternate attractors or basins of attraction (Walker et al. 2004). Coral-to-macroalgae regime shifts cause severe changes in a coral ecosystem by altering biotic interactions, disrupting trophic structure, lowering biodiversity, and changing the productivity of reef fisheries (Hempson et al. 2018).

Since the late twentieth century coral reefs have been subjected to a new range of environmental threats associated with climate change that can seriously jeopardize their continued existence unless radical change occurs in the governance and management of reef systems (HoeghGuldberg and Bruno 2010, Anthony et al. 2017, Hughes et al. 2017). These threats include increasingly frequent and extensive marine heat waves (Oliver et al. 2018, Babcock et al. 2019), often leading to severe bleaching, and ocean acidification that modifies carbonate chemistry and reef calcification (Hoegh-Guldberg et al. 2007). Coral bleaching is caused by the synergistic effect of elevated light and temperature, leading to the breakdown of normal symbiont photosynthetic pathways and causing damage to the host and expulsion of the algal symbionts (Lesser and Farrell 2004). Although mass coral bleaching appears to be a relatively recent phenomenon with reports first emerging in the 1980s (Glynn 1983), the problem has rapidly amplified with mass bleaching events occurring in the late 1990s (Lough 2000) and again during 2015-16, the latter affecting $75 \%$ of Indo-Pacific coral reefs, including $84 \%$ of Australia's tropical reefs (Hughes et al. 2018a). 
66

Interestingly, reduced incoming light due to cloudy conditions has been shown to mitigate bleaching in the Pacific (Mumby et al. 2001). Coral reefs within or near the western Pacific warm pool (WPWP) - the so-called "coral triangle" - have had fewer reported bleaching events relative to reefs in other regions (Kleypas et al. 2008). Analysis of sea surface temperature (SST) indicates the warmest parts of the WPWP have warmed less than elsewhere in the tropical oceans, supporting the existence of a thermostat mechanism that depresses warming beyond certain temperature thresholds. One of the suggested thermostat mechanisms was via a cloud-SST feedback (Ramanathan and Collins 1991), with a more detailed description of cloud feedbacks given by Stephens (2005).

Over the past 10-15 years, field and laboratory studies have provided evidence for the existence of a hitherto unrecognized climate bio-regulation process in coral reefs (Broadbent et al. 2002, Broadbent and Jones 2004, Jones 2015). This is through the production of a suite of volatile compounds that can act as precursors of marine biogenic aerosol (MBA) in response to physiological stress experienced by the coral related to high irradiance or ocean temperature. In remote marine atmospheres, these secondary biogenic aerosols are thought to influence the local radiative budget through backscattering of incoming short-wave solar radiation, and indirectly through their effect on cloud microphysics and precipitation forming processes. The climate regulation potential of MBA was first discussed over 30 years ago by Charlson and co-authors (1987), with the so-called "CLAW hypothesis" spawning a plethora of related research regarding the possibility of a natural thermostat which would offset the warming caused by anthropogenic greenhouse gases (GHG). This research theme has proved to be remarkably resilient and continues to the present day (Gabric et al. 2018, Mahmood et al. 2019), although the strength and sign of any MBA feedback on climate warming is likely to be regionally variable and is still uncertain at the global scale (Ayers and Cainey 2007, Heinze et al. 2019).

Our understanding of aerosol-climate interactions although growing, is still incomplete, being identified by the Intergovernmental Panel on Climate Change (IPCC) as one of the key sources of uncertainty in our knowledge of Earth's energy budget and anthropogenic climate forcing (Schneider et al. 2017, Simpkins 2018). This is particularly true of coral reef ecosystems where the relationship between MBA emissions and coral physiological stress is complex (Jackson et al. 2018) . Here we review the current knowledge of MBA emissions from coral reef ecosystems, examine changes in aerosol emissions as a response to physiological stressors and discuss the implications for the future resilience of coral reefs in response to climate change related stressors. 


\section{Survey Methodology}

The quite separate fields of coralline ecology and aerosol-climate interactions both have a long and rich history. Unsurprisingly however, given the distinct disciplines involved, the intersection of these fields is relatively recent. Indeed, most of the published research on biogenic aerosol emissions by coral reefs has appeared in the last two decades. Notwithstanding the emerging nature of the field, there are numerous aspects of the topic that bridge the disciplines of climatology, aerosol science and coral reef ecology. Consequently, we have chosen to employ an integrative or critical review approach. Our aim is to assess the current evidence for coral reef bio-regulation of climate and to synthesize the literature in a way that will enable a new theoretical framework and paradigm to emerge (Torraco 2005, Torraco 2016). Literature searches were conducted using the key bibliographic databases both full text, such as Web of Science and Google Scholar and Abstract only databases, such as Scopus. The search time frame was limited to the last 30 years as most of the relevant literature has been published relatively recently. Boolean searches were used to narrow the results to capture the literature on both coral reefs and aerosols. Search terms such as "coral stress", "aerosol emissions", "dimethylsulfide AND corals" were used.

\section{Marine Biogenic Aerosol}

Aerosols are minute solid or liquid particles suspended in the atmosphere and are derived from a variety of natural and anthropogenic sources, ranging from industrial processes, volcanic eruptions, biomass burning and marine ecological processes. Aerosol particles are either emitted directly to the atmosphere (primary aerosols) or produced in the atmosphere from precursor gases (secondary aerosol). All atmospheric aerosols scatter incoming solar radiation, and a few aerosol types (e.g. black carbon) can also absorb solar radiation. Aerosols that mainly scatter solar radiation have a cooling effect, by enhancing the total reflected solar radiation from the Earth (Twomey 1977). However, it is the interaction of some aerosols with clouds that leads to a suite of complex but radiatively important effects. The concentration of droplets in clouds that influences planetary albedo is sensitive to the availability of aerosol particles on which the droplets form. An impact on cloud droplet numbers affects rain formation, and thus the cooling effect may be further enhanced by suppressed precipitation followed by increased cloud lifetime, cloud amount and 
130 cloud extent (Albrecht 1989, Pincus and Baker 1994). However, notwithstanding recent progress

131 in our understanding of aerosol-climate interactions, there is still uncertainty about the links

132 between microphysical and larger scale mechanisms, and how climate feedbacks may be

133 affected (Fan et al. 2016, Brooks and Thornton 2018).

134 The most convincing evidence for aerosol modulation of cloud properties has been seen in the 135 marine atmosphere (Hegg 1999, Hegg et al. 2004), specifically the increase in albedo of marine 136 stratocumulus clouds, which cover about a third of the global oceans. Over the last two decades, 137 the availability of satellite-based data has enabled a better understanding of MBA, which has 138 been shown to play an important role in the radiative budget of remote marine atmospheres and 139 potentially shaping regional climate (McCoy et al. 2015, Fan et al. 2016, Vergara-Temprado et al. 140 2018). However, despite over three decades of research, there are still gaps in our understanding 141 of the effect of aerosol-cloud interactions on climate (Ayers and Cainey 2007, Carslaw et al. 142 2013). MBA can be primary aerosols consisting of sea-salt and particulate organic matter (Leck 143 and Bigg 2005, Orellana et al. 2011, Modini et al. 2015), or secondary aerosols formed through 144 the atmospheric oxidation of volatile precursor compounds, such as dimethylsulfide (DMS) 145 (Andreae and Crutzen 1997), organo-halogens (O'Dowd et al. 2002) and other organic 146 compounds. In the original CLAW hypothesis MBA precursor compounds such as DMS were 147 thought to be synthesized solely by pelagic phytoplankton, but as shown in Figure 1, other 148 organisms such as corals and benthic algae are also known to be sources (Broadbent and Jones 149 2004, Raina et al. 2013, Burdett et al. 2015)., It is now recognized that the synthesis and emission 150 of these biogenic climate active compounds is shaped by a range of marine ecosystem processes 151 (Liss et al. 2000, Carslaw et al. 2010). Thus, the sea-to-air flux of these aerosol precursor 152 compounds and particles depends in a complex fashion on the structure and dynamics of the 153 entire marine food web (Simó 2001).

157 The effect of an change in atmospheric aerosol concentrations on the distribution and radiative 158 properties of Earth's clouds is the most uncertain component in model projections of the global 159 radiative forcing of climate (Seinfeld et al. 2016). This makes it imperative to investigate the 160 current and future sources of these climate-active compounds. However, there are several factors 161 that constrain an improved estimate of the effect of aerosol-cloud interactions. Although 162 aerosol-cloud processes are reasonably well understood at the scale of a single cloud, the 
163

164

165

166

167

168

169

170

171

172

173

174

175

176

177

178

179

180

181

182

183

184

185

186

187

188

189

190

191

192

193

194

195

difference in scale between the spatial resolution of general circulation models (GCMs) and individual cloud processes introduces considerable uncertainties (Seinfeld et al. 2016). Secondly, the change in future aerosol emissions is uncertain, with anthropogenic emission trends already negative in developed economies (Zhao et al. 2017). This trend is likely to be reinforced as pollution controls are implemented in developing economies which are suffering serious impacts from particulate air pollution (Huang et al. 2014, Samset et al. 2018).

The role of natural aerosol emissions in cloud radiative forcing is less certain but thought to be even greater than that due to anthropogenic aerosol (Carslaw et al. 2013). With respect to future trends in natural aerosol emissions such as sulfur-containing MBA, the model projections vary markedly depending on the ocean region considered and the model complexity and parametrizations used (Gabric et al. 2004, Gabric et al. 2005, Cameron-Smith et al. 2011, Six et al. 2013a, Menzo et al. 2018). In the rapidly warming Arctic Ocean decadal data on DMS suggests a positive trend in emissions (Galí et al. 2019). In other parts of the global ocean the trend is not clear, often due to sparseness of the existing database. This is particularly true for the Southern Ocean where the sparse databases are currently being augmented and improved (Jarníková and Tortell 2016, Webb et al. 2019). Modelling experiments suggest that increasing atmospheric greenhouse gas concentrations may enhance future DMS emissions, and thus sulfate aerosol concentrations, in both the Arctic and Southern Oceans, introducing a negative feedback to offset the warming (Gabric et al. 2001, Gabric et al. 2005, Qu et al. 2015, Kim et al. 2018). Increasing ocean acidification may also impact marine DMS emissions, although the sign of the feedback appears to be regionally variable (Wingenter et al. 2007, Archer et al. 2013, Six et al. 2013b, Archer et al. 2018).

Aerosol Precursors in Coral Reefs

Reef-building corals are prolific producers of dimethylsulfoniopropionate (DMSP), a central molecule in the marine sulfur cycle and precursor of DMS (Broadbent and Jones 2004). Both DMS and DMSP are particularly abundant in coral reef ecosystems (Jones et al. 1994, Hill et al. 1995), being present in macroalgae (Broadbent et al. 2002), coralline algae (Burdett et al. 2015), soft corals (Haydon et al. 2018) and also detected in coral polyps themselves (Raina et al. 2013). DMSP is produced by both the algal endosymbiont Symbiodinium (Hill et al. 1995) and coral host (Raina et al. 2013) which, together with the breakdown products DMS and dimethyl sulfoxide (DMSO), has various roles in coral reef ecosystems, including oxidative stress protection 
196 (Deschaseaux et al. 2016, Gardner et al. 2017). It has become increasingly clear that the whole 197 coral holobiont (comprised of the coral animal and its associated microorganisms consisting of 198 bacteria, fungi, viruses, and protists including the dinoflagellate algae Symbiodinium) are all to 199 some degree involved in the synthesis and cycling of these sulfur compounds (Raina et al. 2010).

200 The first hint of a link between coral physiological stress and DMS(P) was noted some decades 201 ago in the Florida keys, where extremely high concentrations of atmospheric DMS were observed 202 after aerial exposure of the reef at low tide (Andreae et al. 1983), and later a possible effect of 203 stress-related DMS emissions on the local reef climate was also hypothesized (Hill et al. 1995) . 204 A detailed treatment of the anti-oxidant role of dimethylated sulfur compounds was first reported 205 for pelagic phytoplankton by Sunda et al. (2002). More recently this has been extended to other 206 marine organisms such as benthic algae (Burdett et al. 2015) and corals themselves 207 (Deschaseaux et al. 2014a). The anti-oxidant role of DMSP is especially evident in Acropora 208 corals (Gardner et al. 2016), the dominant species throughout the Great Barrier Reef (GBR), 209 Australia. Acropora are among the highest producers of DMS and increased emissions have been 210 detected in response to increases in sea temperature, solar irradiance and osmotic stress 211 (Fischer and Jones 2012, Swan et al. 2017). Seasonal increases in DMS emissions from coral 212 reefs have been observed during low tides when the reef can be aerially exposed (Hopkins et al. 213 2016, Jones et al. 2018b). If aerial exposure coincides with high irradiance then significant coral 214 mortality can occur (Anthony and Kerswell 2007). Corals can also be stressed during periods of 215 high rainfall when hyposalinity may affect coral physiology (Gardner et al. 2016, Aguilar et al. 216 2017).

217 Notwithstanding the recent progress in the field, there is limited understanding of the mechanisms 218 of DMS production by the coral holobiont and relatively sparse data on either dissolved or 219 atmospheric DMS concentrations in coral reef areas. Similarly, estimates of DMS fluxes to the 220 atmosphere from reefal environments are as yet poorly constrained and not included in global 221 DMS data bases such as that of Lana et al. (2011).

\section{Effects on local climate}

Although the nexus between MBA emissions and changes in the properties of maritime clouds has been debated for a long time (Ayers and Cainey 2007), significant progress in the 
229 interactions over large swaths of the global ocean. Several studies have shown a strong 230 correlation between MBA and marine cloud cover and cloud properties (Kruger and Grassl 2011, 231 Lana et al. 2012, McCoy et al. 2015). Notwithstanding this, a recent comprehensive review 232 concluded that the relationship between marine biogeochemical processes and cloud formation 233 is potentially significant but still poorly defined (Brooks and Thornton 2018).

234 In pristine coral reefs such as the WPWP, DMS emissions are thought to be the key driver behind 235 an ocean thermostat which suppresses ocean warming below coral thermal tolerance thresholds $236\left(\sim 30^{\circ} \mathrm{C}\right)$ through a build-up of low-level clouds (LLC), as shown in Figure 2. Despite corals in the 237 WPWP living close to their thermal maxima, few coral bleaching events have been recorded in 238 this region, and although uncertain (due to the possible under-reporting of bleaching events) this 239 resilience to heat stress is thought to be due to cloudiness (Kleypas et al. 2008, Kleypas et al. 240 2015). The role of cloud cover in moderating the intensity of bleaching in the Society Islands was 241 also noted by Mumby et al. (2001). In the GBR, a decadal analysis of the connection between

242 bleaching and solar radiation showed that the area of maximum bleaching corresponded closely 243 to the area of maximum solar insolation (Masiri et al. 2008). Some evidence points to a similar 244 aerosol-climate feedback mechanism operating in the GBR, where although ocean temperatures 245 in north-eastern Australia are warming, SSTs in the northern GBR are rising at a slower rate 246 compared to southern regions (Lough 2008). As conjectured for the WPWP, this may be due to 247 the high biomass of DMS(P)-producing corals and the accumulation of DMS-rich air in the 248 prevailing south-east trade winds over the GBR (Jones and Trevena 2005, Jones et al. 2017).

249 An 18-year time series study (Jackson et al. 2018) of satellite-derived fine-mode aerosol optical 250 depth (AOD) in the GBR found that AOD correlated positively with SST and irradiance and 251 increased two-fold during spring and summer. Jackson et al. (2018) posit that the positive 252 correlation between AOD and both SST and irradiance is consistent with enhanced DMS-derived 253 particle formation over the GBR.

255 Case study: The Great Barrier Reef (GBR), Australia 256

257 The GBR is the world's largest coral reef ecosystem, consisting of 3,000 individual coral reefs 258 spanning $2,300 \mathrm{~km}$ of the north-eastern Australian coastline $\left(10^{\circ} \mathrm{S}-24^{\circ} \mathrm{S}\right.$ ) (See Figure 3 ). The 259 Great Barrier Reef Marine Park (GBRMP) was established in 1975 to manage a diversity of 
260

261

262

263

264

265

266

267

268

269

270

271

272

273

274

275

276

277

278

279

280

281

282

283

284

285

286

287

288

289

290

291

292

species, including more than 400 Scleractinian (stony) corals, 1,500 species of fish, 30 species of marine mammals and six of the seven species of marine turtles. The diversity and size of the GBR makes it incredibly important for tourism, fisheries, ecosystem services (reviewed in Stoeckl (2011)). Acropora spp. are the dominant coral genus throughout the GBR and Indo-Pacific and are strong producers of climatically active dimethylated sulfur compounds (Raina et al. 2013, Swan et al. 2016). The GBR and lagoon waters $\left(347,000 \mathrm{~km}^{2}\right)$ are estimated to emit $20 \mathrm{Gg} \mathrm{S}$ year $^{-1}$ as DMS (Jones et al. 2018a) and may therefore play an important role in local climate.

The climate of the GBR ranges from sub-equatorial in the north, to sub-tropical in the south, with hot monsoonal summers (November - April) and dry, mild winters (May - October). Corals upregulate the biosynthesis of DMSP and catabolism to DMS during physiological stress caused by exposure to elevated SST and solar irradiance, or due to low salinity associated with seasonal rainfall and riverine discharge (Raina et al. 2013, Deschaseaux et al. 2014a, Jones et al. 2014). These processes likely drive seasonal increases in DMS emissions from the GBR during spring and summer (Broadbent and Jones 2006, Jones et al. 2018a). Seasonally aberrant spikes in atmospheric DMS $\left(D^{2} S_{a}\right)$ also occur when the coral reef is aerially exposed at low tide (Hopkins et al. 2016, Swan et al. 2017), with atmospheric concentrations reaching $45 \mathrm{nmol} \mathrm{m}$-3 (Table 1) over corals at Heron Island in the southern GBR (Swan et al. 2017). Similar to the CLAW hypothesis, it is possible that coral reef emissions of DMS may influence the chemical and physical properties of aerosols and cloud condensation nuclei ( $\mathrm{CCN})$, thereby increasing the radiative cooling effect of low-level marine clouds over coral reefs. Whether this effect exerts a regional climate impact depends on a number of factors. Any local climate feedback depends on the spatial extent of the reef system, and the strength and direction of prevailing winds which could transport aerosols and their precursor compounds away from the reefal source area (Cropp et al. 2018). The large spatial extent of the GBR makes it the most likely candidate for a local aerosol-climate feedback.

\section{Aerosol Climatology of the GBR}

Prevailing south-easterly winds accumulate marine aerosols as air is advected northward along the GBR. These aerosols largely consist of clusters of sea-salt, organics (Mallet et al. 2016) and non-sea salt sulfates derived from DMS (Modini et al. 2009, Swan et al. 2016). Aerosol emissions vary seasonally and meridionally in the GBR (Jackson et al. 2018). In the northern GBR, aerosol loading is highest during the winter dry season and early spring (Jackson et al. 2020), coinciding 
293

294

295

296

297

298

299

300

301

302

303

304

305

306

307

308

with frequent biomass burning and wildfires on the Australian continent (Harris et al. 2008). Here, the situation is complex as the marine biogenic source of aerosol is likely augmented by continental aerosol sources, with quite different composition (carbonaceous) and radiative properties (Langmann et al. 2009). Dust storms from the arid inland regions of the continent can also traverse the GBR region later in spring, but these events are episodic and their likelihood of occurrence is low (Cropp et al. 2013). Conversely, in the southern GBR (>15 S), seasonal, high frequency increases in aerosol occur in spring and summer, followed by a decline in winter (Cropp et al. 2018, Jackson et al. 2018). This seasonal cycle is commonly observed in the remote MBL and is driven by temperature and irradiance-dependent shifts in ocean biology (Korhonen et al. 2008, McCoy et al. 2015, Gabric et al. 2018). Seasonal peaks in phytoplankton biomass are usually found during the summer wet season when fluvial nutrient loads to the inshore GBR are high (Gabric et al. 1990, Brodie et al. 2007). Given the remote location and vast size of the GBR, seasonal shifts in stress-induced emissions of DMS from corals, and other volatile organics such as isoprene from reef sediments (Swan et al. 2016, Hrebien et al. 2020), may be driving the increase in aerosol in spring and summer.

Several studies support the hypothesis that the GBR is a significant source of marine aerosols. Early field studies found that total atmospheric particle concentration was up to seven times higher in maritime air directly over the GBR compared to the adjacent open ocean (Bigg and Turvey 1978). Three decades later, observations of nucleation events at Lizard Island in the northern GBR identified a strong seasonal cycle in atmospheric particle concentration (Leck and Bigg 2008). The concentration of nucleation mode aerosol was an order of magnitude higher in spring, reaching up to $40,000 \mathrm{~cm}^{-3}$, compared to $4,000 \mathrm{~cm}^{-3}$ in winter (Leck \& Bigg 2008), following a similar seasonal cycle to that of DMS emissions from the GBR (Broadbent and Jones 2006, Jones et al. 2018a). Other recent field studies have observed nucleation events in the southern GBR during daylight, low relative humidity ( 60\%) and low wind speeds (Modini et al. 2009, Swan et al. 2016), when conditions for the local gas-phase nucleation of DMS-derived sulfates is favorable (Chang et al. 2011). New fine-mode aerosols ( $\leq 1 \mu \mathrm{m}$ ) consisted of $\sim 40-50 \%$ organics and $50-$ $60 \%$ sulfates, were likely derived from DMS emissions from the coral reef. Remote sensing approaches have also demonstrated a significant correlation between estimates of coral physiological stress and aerosol optical depth (AOD) in the GBR, especially when wind speeds are low allowing for longer aerosol residence time over the reef area (Cropp et al. 2018, Jackson et al. 2018). 


\section{Recent Coral Bleaching Events}

Corals in the GBR are exposed to multiple stressors, including ocean warming, acidification and poor water quality, which individually and synergistically diminish coral resilience and can result in coral bleaching and subsequent mortality (Anon. 2019). Reduced cloud cover and marine heatwaves often coincide with an El Niño phase of the Southern Oscillation Index and are the most common drivers of bleaching events in the GBR (McGowan and Theobald 2017, Hughes et al. 2018b). Over the past two decades, the GBR has experienced five mass thermal bleaching events in the summers of 1997-98, 2001-02, 2005-06, 2015-16 and 2016-17. Inshore coral reefs are particularly vulnerable to declining water quality due to runoff from adjacent catchments and urban areas (Gabric and Bell 1993, Brodie et al. 2011, De'ath et al. 2012). In the summers of 2008-09 and 2010-11, La Nina associated flooding, low salinity and eutrophication combined to result in mass coral bleaching (Thompson et al. 2011, Thompson et al. 2013). These stressors are often exacerbated by destructive wave action and hyposalinity resulting from fluvial inputs or rainfall associated with tropical cyclones, which frequently occur in summer (Anon. 2011, De'ath et al. 2012).

Acropora spp. are temperature-sensitive and are particularly vulnerable to rises in SST (Fischer and Jones 2012, Hughes et al. 2018a). The two most recent mass coral bleaching events occurred due to marine heatwaves in the summers of 2015-16 and 2016-17. SST was well above average in the summer of 2015-16 (Jackson et al. 2018), resulting in wide spread coral bleaching and mortality (Hughes et al. 2018a). This was the worst coral bleaching event on record in the GBR, affecting 92\% of coral reefs in the marine park (Anon. 2017), with Acropora spp. suffering catastrophic mortality (Hughes et al. 2018a). Field surveys conducted by the Australian Institute of Marine Science (AIMS) estimated that $29 \%$ of shallow-water corals were lost reef-wide, with the largest loss reported in the far northern GBR ( 75\%) (Anon. 2017). Corals in the southern GBR were least affected by this event as SST rapidly subsided with category 5 tropical cyclone Winston in late February, although temperature-sensitive Acropora and Pocillopora colonies were still affected (Kennedy et al. 2018).

SST remained above average throughout the GBR in winter 2016 and by the following summer, resulted in a second mass coral bleaching event. Coral mortality was lower in the far northern GBR during this event due to the loss of many temperature sensitive corals during the previous summer (Anon. 2018). Consequently, the most severely affected region shifted south to the northcentral GBR in 2017. Temperature-sensitive spawning corals comprise $\sim 90 \%$ of reef-building 
359

360

361

362

363

364

365

366

367

368

369

370

371

372

373

374

375

376

377

378

379

380

381

382

383

384

385

386

387

388

389

390

391

corals in the GBR, many of which were lost during these consecutive coral bleaching events. Consequently, larval recruitment has fallen by an average of $89 \%$ across the GBR (Hughes et al. 2019) resulting in regional scale shifts in community structure (Hughes et al. 2018b).

\section{Changes in Aerosol Emissions before and after Bleaching Events}

Corals in the GBR increase DMSP biosynthesis and catabolism to DMS in response to oxidative stress (Deschaseaux et al. 2014c). Reactive oxygen species (ROS) are released from zooxanthellae photosystems when damage caused by intense photosynthetically active radiation (PAR) or elevated SST exceeds photoprotective mechanisms (Lesser et al. 1990, Yakovleva et al. 2009). DMSP and particularly DMS, have a high affinity for these ROS (Sunda et al. 2002), and act as an efficient antioxidant system in corals to help protect against stressors leading to coral bleaching. When oxidative stress exceeds coral's photoprotective mechanisms, the rate of DMS(P) oxidation to DMSO increases, and ambient DMS concentrations decline (Fischer and Jones 2012, Deschaseaux et al. 2014a). When Acropora spp. in the southern GBR were exposed to SST $\geq 26^{\circ} \mathrm{C}$ or PAR $\geq 6 \mathrm{~mol} \mathrm{~m}^{-2} \mathrm{hr}^{-1}$, DMS emissions declined by $93 \%$ and $82 \%$, respectively (Fischer and Jones 2012). A decline in DMS emissions results in fewer aerosol precursor compounds and potentially less aerosol formation events and condensational growth of preexisting aerosols above the coral reef.

The non-linearity in coral physiological stress and potential effects on aerosol loading was recently investigated during four mass thermal coral bleaching events between 2001-2017 (Jackson et al. 2018). The coherence between satellite-derived anomalies of fine-mode $(<0.1 \mu \mathrm{m})$ AOD and estimates of coral thermal stress, calculated as degree-heating weeks (DHW), was examined. Prior to coral bleaching, SST increased, and corals were likely emitting large quantities of DMS in an attempt to mitigate thermal stress (Raina et al. 2013). During this time, AOD was highly variable and often above the long-term average (2000 - 2017). However, the pattern of DMS emissions with coral physiological stress is non-linear and shows a decline when the coral thermal stress threshold is exceeded (Fischer and Jones 2012). This threshold or tipping-point was calculated as the climatological maximum summertime SST and ranged from $27.3^{\circ} \mathrm{C}$ at Heron Island in the southern GBR, to $29.1^{\circ} \mathrm{C}$ at Fife Island in the far northern GBR (Jackson et al. 2018) . As SST approached this tipping-point, and DHW and field-based reports indicated that coral bleaching was occurring, AOD declined to average, or below average levels where coral bleaching and mortality was severe (Jackson et al. 2018). The synchronous decline in AOD with 
392 the onset of coral bleaching may have been driven by a decline in DMS and MBA emissions from

393 the coral reef. Although the AOD can be affected by a range of aerosol types, the spatio-temporal

394 coherence between the timing of coral bleaching and sharp AOD changes support the hypothesis

395 of a strong causal link between coral physiological stress and aerosol emissions in the GBR.

396

Reef-scale micrometeorology is an important determinant of the extent and severity of coral bleaching in the GBR (McGowan and Theobald 2017, McGowan et al. 2019). DMS and other volatile biogenic compounds influence aerosol and cloud properties in the remote MBL (Gabric et al. 2013, Fiddes et al. 2018, Sanchez et al. 2018) and likely play an important role in the local climate of the GBR. However, ongoing coral reef degradation and bleaching could lead to a decline in DMS emissions from the GBR, with concerning implications for coral resilience to future temperature rises. A decline in biogenic aerosol emissions could weaken the aerosol and LLC radiative cooling effect in the GBR, exacerbating coral physiological stress and potentially leading to more frequent bleaching events.

Coral DMS(P) biosynthesis increases with thermal and irradiance stress, followed by oxidation by ROS to DMSO in temperature-sensitive species. These species are the dominant reefbuilding corals in the GBR and are the strongest individual producers of DMS(P) (Swan et al. 2016). The rate of oxidation to DMSO determines the amount of DMS available to be ventilated to the MBL. Thus when oxidative stress is high, DMS emissions decline as the concentration of DMSO increases in the coral holobiont (Fischer and Jones 2012, Deschaseaux et al. 2014a). A shift in community structure and decline in the abundance of these species could lead to a significant decline in coral DMS emissions from the GBR. Degraded coral reefs often become dominated by fleshy macroalgae (Bell 1992, McCook 2002, De'ath and Fabricius 2010, Barott and Rohwer 2012), some of which (e.g. Polysiphonia and Ulva spp.) are also capable of producing high concentrations of DMSP (Van Alstyne and Puglisi 2007, Liu et al. 2020) and may counteract a decline in overall coral reef DMS emissions. Recent work has shown that climate change may result in an increase in seawater DMSP concentration in the tropics, primarily due to an increase in DMSP/O biosynthesis in a range of coral reef taxa, and an increase in the biomass of DMSP-producing fleshy macroalgae (Green 2019). However, the 
424 reefs in coping with ongoing climate change via antioxidant activity or climate regulation,

425 remains highly uncertain.

426

427 The ability of corals to adapt to the rapidly changing climate will govern changes to DMS 428 emissions from the GBR. Corals have a close association with a range of microbes and therefore 429 harbor a diverse genome (Bourne et al. 2016) that may facilitate rapid phenotypic change in the 430 coral host (Torda et al. 2017). Corals can also enhance their thermo-tolerance by changing their 431 endosymbiont composition via zooxanthellae switching or shuffling (Bay et al. 2016). Acropora 432 spp. favor Clade D endosymbionts when exposed to thermal stress (Jones and King 2015), which 433 can increase their temperature tolerance by $1.5^{\circ} \mathrm{C}$ (Berkelmans and Van Oppen 2006). This may 434 be enough to maintain internal homeostasis in the coral holobiont and protect against mild to moderate marine heatwaves. However, the predicted rate of ocean warming may still exceed the tolerance thresholds of temperature tolerant coral taxa (van der Zande et al. 2020). Rapid rises in SST remove gradual "warm-up" periods, which are thought to alleviate temperature shock in corals, helping to mitigate oxidative stress prior to past bleaching events (Ainsworth et al. 2016). Temperature-tolerant endosymbionts are typically weaker producers of DMSP under current conditions (Deschaseaux et al. 2014b, Bay et al. 2016), although tolerance does not always predict DMSP biosynthesis (Steinke et al. 2011) and will depend on the rate of future ocean warming.

\section{Conclusions}

Biogenic emissions of DMS are a significant source of atmospheric sulfur, which in remote marine environments, is an important source of secondary sulfate aerosols. These non-sea salt sulfates play a significant role in the local climate of these remote marine environments, yet emissions of natural aerosols and their precursors remains one of the largest contributors to our uncertainty in aerosol radiative forcing (Carslaw et al. 2013), and ultimately our understanding of what determines the climate sensitivity.

452

Pristine, coral reef dense regions such as the GBR, are particularly strong sources of atmospheric DMS, similar in magnitude to highly productive high-latitude oceans. Corals upregulate the 
455

456

457

458

459

460

461

462

463

464

465

466

467

468

469

470

471

472

473

474

475

476

477

478

479

480

481

482

483

484

485

processes important in maintaining coral homeostasis and promoting resilience to rising ocean temperatures. It is hypothesized that coral reef emissions of DMS increase the formation and condensational growth of marine aerosols and CCN, thereby increasing the brightness, lifetime and cover of low-level marine clouds. Local cloud cover is an important determinant of the spatial extent and severity of coral physiological stress and coral bleaching. Thus, enhanced MBA emissions and LLC cover may establish a negative feedback over coral reefs to mitigate coral physiological stress.

This review has discussed evidence of significant links between coral physiological stress, DMS emissions, aerosol loading and local cloud cover over coral reefs, highlighted by a case study on the GBR, Australia. Given the vast size and relatively remote, pristine location of the GBR, it is possible that the $20 \mathrm{GgSyr}^{-1}$ emitted from the 3,000 individual coral reefs and surrounding lagoon waters significantly influences aerosol and cloud properties in north-eastern Australia. However, there remains substantial uncertainty surrounding the importance of DMS emissions in the properties of the local atmosphere above coral reefs, and what implications ongoing coral reef degradation may have on these complex biogeochemical processes.

\section{Future Directions}

The current rate of ocean warming and coral reef degradation increases the urgency at which we must improve our understanding of the importance of DMS in the coral reef radiative climate. Nonlinear changes in DMS emissions have been reported in response to thermal and light stress in corals (Fischer and Jones 2012, Jackson et al. 2018). However, the impacts of ocean warming are being exacerbated by ocean acidification, declining water quality and increased susceptibility to disease, predation and competitive displacement. The synergistic impacts of these co-varying stressors on DMS emissions from coral reefs are largely unknown.

It is possible that rising ocean temperatures will lead to an increase in DMS emissions from coral reefs, although as indicate above, there are limits on the DMS increase associated with the onset of bleaching (Jackson et al. 2018). This possibility could be examined through a modeling approach akin to those used to project future change in open ocean DMS emissions under warming, eg (Cameron-Smith et al. 2011, Gabric et al. 2013). This approach is limited by the sparse DMS database in coral reef regions (Lana et al. 2011), which currently constrains our 
486

487

488

489

490

491

492

493

494

495

496

497

498

499

500

501

502

503

504

505

506

507

508

509

510

511

512

513

514

515

516

517

518

ability to derive empirical parametrisatons between DMS water concentration and sea temperature. This may also be complicated if corals are capable of acclimating to rising stressors (Jurriaans and Hoogenboom 2020), or if coral reefs become dominated by more temperaturetolerant species or zooxanthellae types which do not experience significant oxidative stress under warmed conditions. Interestingly, field surveys of the GBR have demonstrated that concentrations of dissolved DMS decline along a gradient of healthy to disturbed coral reefs (Jones et al. 2007). Consequently, DMS sea-air flux will likely be lower for coral reefs that are exposed to multiple synergistic stressors. Although, as noted above, DMS $(P)$ biosynthesis from enhanced algal biomass in degraded coral reef systems may counteract a decline in coralline emissions. These are critical areas for future research and will inform the importance of coral reef emissions of biogenic sulfates in local climate regulation.

The predicted increase in the frequency and severity of mass coral bleaching events may require the implementation of biological and/or physical interventional management strategies. The propagation of temperature-tolerant coral species may allow coral reefs to recover from recent bleaching events (van Oppen et al. 2015). Physically mitigating the warming effects of GHG through solar radiation management (SRM) may also assist corals in coping with future temperature rises. SRM strategies essentially mimic natural biogeophysical processes and involve injecting SSA or sulfates into the atmosphere above coral reefs to increase the brightness of LLC (Crabbe 2009, Latham et al. 2013, Irvine et al. 2017). Several modelled scenarios have found that this significantly reduces the incidence of mass coral bleaching predicted to occur in the GBR, French Polynesia, Caribbean and other tropical coral reefs to the end of this century (Latham et al. 2013, Kwiatkowski et al. 2015, Zhang et al. 2018). An additional benefit of these SRM strategies is the potential reduction in the severity of tropical cyclones with a decline in SST. Although climate engineering is a cost and resource-intensive option, it may be necessary to provide short-term protection for high-value or vulnerable coral reefs from rising temperatures.

There is enormous incentive to improve our understanding of the drivers of coral resilience, including the role of dimethylated sulfur compounds in alleviating oxidative stress and influencing the radiative balance. Future research needs to focus on the quantification and characterization of the flux of these compounds from coral reefs and its influence on aerosol and cloud formation. An improved understanding of these biogeophysical processes will provide insight into how to enhance the natural defense mechanisms of corals and inform climate engineering proposals, which may need to be implemented as a last resort to conserve coral reefs in the face of ongoing climate change. 


\section{FIGURE CAPTIONS}

521

522 Figure 1. Simplified overview of the cycling of reduced sulfur compounds in coral reef seawaters 523 and their role in coral homeostasis. Corals upregulate dimethylsulfide (DMSP) biosynthesis and 524 cleavage to dimethylsulfide (DMS) in response to physiological stress. DMS(P) scavenge reactive oxygen to mitigate oxidative damage, forming dimethyl sulfoxide (DMSO).

Figure 2. Summary of the influence of dimethylsulfide (DMS) emissions on marine aerosol, cloud condensation nuclei (CCN) and low-level clouds (LLC) over coral reefs. DMS is oxidized by hydroxyl radicals $(\mathrm{OH})$ to sulfur dioxide $\left(\mathrm{SO}_{2}\right)$ and secondarily to sulfuric acid $\left(\mathrm{H}_{2} \mathrm{SO}_{4}\right)$. DMSderived sulfates may condense onto pre-existing aerosols or undergo homogenous nucleation to form new non-sea salt sulfate $\left(\mathrm{nns}-\mathrm{SO}_{4}\right)$ particles, which can influence the local radiative

532 balance.

533 Figure 3. Diverse coral community at Norman Reef in the northern Great Barrier Reef, Australia. 534 Source: Rebecca Jackson. 
536

537

538

539

540

541

542

543

544

545

546

547

548

549

550

551

552

553

554

555

556

557

558

559

560

561

562

563

564

565

566

567

568

569

570

571

572

573

574

575

576

\section{References}

Aguilar, C., J.-B. Raina, C. A. Motti, S. Fôret, D. C. Hayward, B. Lapeyre, D. G. Bourne and D. J. Miller (2017). "Transcriptomic analysis of the response of Acropora millepora to hypo-osmotic stress provides insights into DMSP biosynthesis by corals." BMC Genomics 18(1): 612.

Ainsworth, T. D., S. F. Heron, J. C. Ortiz, P. J. Mumby, A. Grech, D. Ogawa, C. M. Eakin and W. Leggat (2016). "Climate change disables coral bleaching protection on the Great Barrier Reef." Science 352(6283): 338-342.

Albrecht, B. A. (1989). "Aerosols, cloud microphysics, and fractional cloudiness." Science 245: $1227-$ 1230 .

Andreae, M., W. Barnard and J. Ammons (1983). "The biological production of dimethylsulfide in the ocean and its role in the global atmospheric sulfur budget." Ecological Bulletins: 167-177.

Andreae, M. O. and P. J. Crutzen (1997). "Atmospheric aerosols: Biogeochemical sources and role in atmospheric chemistry." Science 276: 1052-1058.

Anon. (2011). Impacts of tropical cyclone Yasi on the Great Barrier Reef: a report on the findings of a rapid ecological impact assessment, July 2011, Great Barrier Reef Marine Park Authority.

Anon. (2017). 2016 coral bleaching event on the Great Barrier Reef, Great Barrier Reef Marine Park Authority.

Anon. (2018). Long-term Reef Monitoring Program: Annual Summary Report on Coral Reef Condition for 2017/18, Australian Institute of Marine Science.

Anon. (2019). Great Barrier Reef Outlook Report 2019, Great Barrier Reef Marine Park Authority.

Anthony, K., L. K. Bay, R. Costanza, J. Firn, J. Gunn, P. Harrison, A. Heyward, P. Lundgren, D. Mead, T. Moore, P. J. Mumby, M. J. H. van Oppen, J. Robertson, M. C. Runge, D. J. Suggett, B. Schaffelke, D. Wachenfeld and T. Walshe (2017). "New interventions are needed to save coral reefs." Nature Ecology \& Evolution 1(10): 1420-1422.

Anthony, K. and A. Kerswell (2007). "Coral mortality following extreme low tides and high solar radiation." Marine Biology 151(5): 1623-1631.

Archer, S. D., S. A. Kimmance, J. A. Stephens, F. E. Hopkins, R. G. J. Bellerby, K. G. Schulz, J. Piontek and A. Engel (2013). "Contrasting responses of DMS and DMSP to ocean acidification in Arctic waters." Biogeosciences 10(3): 1893-1908. 
577

578

579

580

581

582

583

584

585

586

587

588

589

590

591

592

593

594

595

596

597

598

599

600

601

602

603

604

605

606

607

608

609

610

611

612

613

614

615

616

617

618

Archer, S. D., K. Suffrian, K. M. Posman, L. T. Bach, P. A. Matrai, P. D. Countway, A. Ludwig and U. Riebesell (2018). "Processes That Contribute to Decreased Dimethyl Sulfide Production in Response to Ocean Acidification in Subtropical Waters." Frontiers in Marine Science 5: Art. Nr. 245.

Ayers, G. P. and J. M. Cainey (2007). "The CLAW hypothesis: a review of the major developments." Environmental Chemistry 4(6): 366-374.

Babcock, R. C., R. H. Bustamante, E. A. Fulton, D. J. Fulton, M. D. E. Haywood, A. J. Hobday, R. Kenyon, R. J. Matear, E. E. Plagányi, A. J. Richardson and M. A. Vanderklift (2019). "Severe Continental-Scale Impacts of Climate Change Are Happening Now: Extreme Climate Events Impact Marine Habitat Forming Communities Along 45\% of Australia's Coast." Frontiers in Marine Science 6(411).

Barott, K. L. and F. L. Rohwer (2012). "Unseen players shape benthic competition on coral reefs." Trends in microbiology 20(12): 621-628.

Bay, L. K., J. Doyle, M. Logan and R. Berkelmans (2016). "Recovery from bleaching is mediated by threshold densities of background thermo-tolerant symbiont types in a reef-building coral." Royal Society open science 3(6): 160322.

Bell, P. (1992). "Eutrophication and coral reefs_-some examples in the Great Barrier Reef lagoon." Water Research 26(5): 553-568.

Bell, P. F., I. Elmetri and B. Lapointe (2014). "Evidence of Large-Scale Chronic Eutrophication in the Great Barrier Reef: Quantification of Chlorophyll a Thresholds for Sustaining Coral Reef Communities." AMBIO 43(3): 361-376.

Berkelmans, R. and M. J. Van Oppen (2006). "The role of zooxanthellae in the thermal tolerance of corals: a 'nugget of hope' for coral reefs in an era of climate change." Proceedings of the Royal Society B: Biological Sciences 273(1599): 2305-2312.

Bestelmeyer, B. T., A. M. Ellison, W. R. Fraser, K. B. Gorman, S. J. Holbrook, C. M. Laney, M. D. Ohman, D. P. Peters, F. C. Pillsbury and A. Rassweiler (2011). "Analysis of abrupt transitions in ecological systems." Ecosphere 2(12): 1-26.

Bigg, E. K. and D. E. Turvey (1978). "Sources of atmospheric particles over Australia " Atmospheric Environment 12(8): 1643-1655.

Bourne, D. G., K. M. Morrow and N. S. Webster (2016). "Insights into the coral microbiome:

underpinning the health and resilience of reef ecosystems." Annual Review of Microbiology 70: 317-340.

Peer) reviewing PDF | (2020:02:46057:2:1:NEW 26 Aug 2020) 
619 Broadbent, A. and G. Jones (2006). "Seasonal and diurnal cycles of dimethylsulfide,

620 dimethylsulfoniopropionate and dimethylsulfoxide at One Tree Reef lagoon." Environmental Chemistry

621 3(4): 260-267.

622

623

624

625

626

627

628

629

630

631

632

633

634

635

636

637

638

639

640

641

642

643

644

645

646

647

648

649

650

651

652

653

654

655

656

657

658

659
Broadbent, A. D. and G. B. Jones (2004). "DIMS and DMSP in mucus ropes, coral mucus, surface films and sediment pore waters from coral reefs in the Great Barrier Reef." Marine and Freshwater Research 55(8): 849-855.

Broadbent, A. D., G. B. Jones and R. J. Jones (2002). "DMSP in corals and benthic algae from the Great Barrier Reef." Estuarine Coastal and Shelf Science 55(4): 547-555.

Brodie, J., G. De'ath, M. Devlin, M. Furnas and M. Wright (2007). "Spatial and temporal patterns of nearsurface chlorophyll a in the Great Barrier Reef lagoon." Marine and Freshwater Research 58(4): 342-353.

Brodie, J. E., M. Devlin, D. Haynes and J. Waterhouse (2011). "Assessment of the eutrophication status of the Great Barrier Reef lagoon (Australia)." Biogeochemistry 106(2): 281-302.

Brooks, S. D. and D. C. O. Thornton (2018). "Marine Aerosols and Clouds." Annual Review of Marine Science 10(1): 289-313.

Burdett, H. L., A. D. Hatton and N. A. Kamenos (2015). "Coralline algae as a globally significant pool of marine dimethylated sulfur." Global Biogeochemical Cycles 29(10): 1845-1853.

Cameron-Smith, P., S. Elliott, M. Maltrud, D. Erickson and O. Wingenter (2011). "Changes in dimethyl sulfide oceanic distribution due to climate change." Geophysical Research Letters 38.

Carslaw, K. S., O. Boucher, D. V. Spracklen, G. W. Mann, J. G. L. Rae, S. Woodward and M. Kulmala (2010). "A review of natural aerosol interactions and feedbacks within the Earth system." Atmospheric Chemistry and Physics 10(4): 1701-1737.

Carslaw, K. S., L. A. Lee, C. L. Reddington, K. J. Pringle, A. Rap, P. M. Forster, G. W. Mann, D. V. Spracklen, M. T. Woodhouse, L. A. Regayre and J. R. Pierce (2013). "Large contribution of natural aerosols to uncertainty in indirect forcing." Nature 503(7474): 67-71.

Chang, R. Y. W., S. J. Sjostedt, J. R. Pierce, T. N. Papakyriakou, M. G. Scarratt, S. Michaud, M. Levasseur, W. R. Leaitch and J. P. D. Abbatt (2011). "Relating atmospheric and oceanic DMS levels to particle nucleation events in the Canadian Arctic." Journal of Geophysical Research-Atmospheres 116.

Charlson, R. J., J. Lovelock, M. O. Andreae and S. G. Warren (1987). "Oceanic phytoplankton, atmospheric sulphur, cloud albedo and climate." Nature 326: 655-661. 
660 Costanza, R., R. de Groot, P. Sutton, S. van der Ploeg, S. J. Anderson, I. Kubiszewski, S. Farber and R.

661 K. Turner (2014). "Changes in the global value of ecosystem services." Global Environmental Change 26: $662 \quad 152-158$.

663

664

665

666

667

668

669

670

671

672

673

674

675

676

677

678

679

680

681

682

683

684

685

686

687

688

689

690

691

692

693

694

695

696

697

698

699

700

701

702

703
Crabbe, M. J. C. (2009). "Modelling effects of geoengineering options in response to climate change and global warming: Implications for coral reefs." Computational Biology and Chemistry 33(6): 415-420.

Cropp, R., A. Gabric, D. van Tran, G. Jones, H. Swan and H. Butler (2018). "Coral reef aerosol emissions in response to irradiance stress in the Great Barrier Reef, Australia." AMBIO 47(6): 671-681.

Cropp, R. A., A. J. Gabric, M. Levasseur, G. H. McTainsh, A. Bowie, C. S. Hassler, C. S. Law, H. McGowan, N. Tindale and R. V. Rossel (2013). "The likelihood of observing dust-stimulated phytoplankton growth in waters proximal to the Australian continent." Journal of Marine Systems 117: 43-52.

De'ath, G. and K. Fabricius (2010). "Water quality as a regional driver of coral biodiversity and macroalgae on the Great Barrier Reef." Ecological applications 20(3): 840-850.

De'ath, G., K. E. Fabricius, H. Sweatman and M. Puotinen (2012). "The 27-year decline of coral cover on the Great Barrier Reef and its causes." Proceedings of the National Academy of Sciences 109(44): 17995-17999.

Deschaseaux, E., G. Jones and H. Swan (2016). "Dimethylated sulfur compounds in coral-reef ecosystems." Environmental Chemistry 13(2): 239-251.

Deschaseaux, E., G. B. Jones, M. A. Deseo, K. M. Shepherd, R. Kiene, H. Swan, P. Harrison and B. Eyre (2014a). "Effects of environmental factors on dimethylated sulfur compounds and their potential role in the antioxidant system of the coral holobiont." Limnology and Oceanography 59(3): 758-768.

Deschaseaux, E. S. M., V. H. Beltran, G. B. Jones, M. A. Deseo, H. B. Swan, P. L. Harrison and B. D. Eyre (2014b). "Comparative response of DMS and DMSP concentrations in Symbiodinium clades C1 and D1 under thermal stress." Journal of Experimental Marine Biology and Ecology 459: 181-189.

Deschaseaux, E. S. M., G. B. Jones, M. A. Deseo, K. M. Shepherd, R. P. Kiene, H. B. Swan, P. L.

Harrison and B. D. Eyre (2014c). "Effects of environmental factors on dimethylated sulfur compounds and their potential role in the antioxidant system of the coral holobiont." Limnology and Oceanography 59(3): 758-768.

Fan, J., Y. Wang, D. Rosenfeld and X. Liu (2016). "Review of Aerosol-Cloud Interactions: Mechanisms, Significance, and Challenges." Journal of the Atmospheric Sciences 73(11): 4221-4252.

Fiddes, S. L., M. T. Woodhouse, Z. Nicholls, T. P. Lane and R. Schofield (2018). "Cloud, precipitation and radiation responses to large perturbations in global dimethyl sulfide." Atmos. Chem. Phys. 18(14): 10177-10198.

Peer) reviewing PDF | (2020:02:46057:2:1:NEW 26 Aug 2020) 
704

705

706

707

708

709

710

711

712

713

714

715

716

717

718

719

720

721

722

723

724

725

726

727

728

729

730

731

732

733

734

735

736

737

738

739

740

741

742

743

744

745

746

747

Fischer, E. and G. Jones (2012). "Atmospheric dimethysulphide production from corals in the Great Barrier Reef and links to solar radiation, climate and coral bleaching." Biogeochemistry 110(1-3): 31-46.

Gabric, A., P. Hoffenberg and W. Boughton (1990). "Spatio-temporal variability in surface Chlorophyll distribution in the Central Great Barrier Reef as derived from CZCS imagery." Marine and Freshwater Research 41(3): 313-324.

Gabric, A., P. Matrai, G. Jones and J. Middleton (2018). "THE NEXUS BETWEEN SEA ICE AND POLAR EMISSIONS OF MARINE BIOGENIC AEROSOLS." Bulletin of the American Meteorological Society 99(1): 61-82.

Gabric, A., B. Qu, P. Matrai and A. Hirst (2005). "A modelling analysis of the response of dimethylsulphide production in the Arctic Ocean to global warming." Transactions on ecology and the environment: 107-116.

Gabric, A. J. and P. R. Bell (1993). "Review of the effects of non-point nutrient loading on coastal ecosystems." Marine and Freshwater Research 44(2): 261-283.

Gabric, A. J., B. Qu, L. Rotstayn and J. M. Shephard (2013). "Global simulations of the impact on contemporary climate of a perturbation to the sea-to-air flux of dimethylsulphide." Australian Meteorology and Oceanography Journal 63(3): 365-376.

Gabric, A. J., R. Simo, R. A. Cropp, A. Hirst and J. Dachs (2004). "Modeling estimates of the global emission of dimethylsulfide under enhanced greenhouse conditions." Global Biogeochemical Cycles 18(2): GB2014.

Gabric, A. J., P. Whetton and R. Cropp (2001). "Dimethylsulphide production in the subantarctic Southern Ocean under enhanced greenhouse conditions." Tellus 53B: 273-287.

Galí, M., E. Devred, M. Babin and M. Levasseur (2019). "Decadal increase in Arctic dimethylsulfide emission." Proceedings of the National Academy of Sciences: 201904378.

Gardner, S. G., D. A. Nielsen, O. Laczka, R. Shimmon, V. H. Beltran, P. J. Ralph and K. Petrou (2016). "Dimethylsulfoniopropionate, superoxide dismutase and glutathione as stress response indicators in three corals under short-term hyposalinity stress." Proceedings of the Royal Society B: Biological Sciences 283(1824): 20152418.

Gardner, S. G., J.-B. Raina, P. J. Ralph and K. Petrou (2017). "Reactive oxygen species (ROS) and dimethylated sulphur compounds in coral explants under acute thermal stress." Journal of Experimental Biology 220(10): 1787-1791.

Glynn, P. W. (1983). "Extensive 'bleaching'and death of reef corals on the Pacific coast of Panama." Environmental Conservation 10(2): 149-154.

Peer] reviewing PDF | (2020:02:46057:2:1:NEW 26 Aug 2020) 
748
Green, T. K. (2019). Climate change effects on dimethylated sulphur dynamics in tropical coral reef systems, University of St Andrews.

Harris, S., N. Tapper, D. Packham, B. Orlove and N. Nicholls (2008). "The relationship between the monsoonal summer rain and dry-season fire activity of northern Australia." International Journal of Wildland Fire 17(5): 674-684.

Haydon, T. D., J. R. Seymour and D. J. Suggett (2018). "Soft corals are significant DMSP producers in tropical and temperate reefs." Marine Biology 165(7): 109.

Hegg, D. A. (1999). "Dependence of marine stratocumulus formation on aerosols." Geophysical Research Letters 26(10): 1429-1432.

Hegg, D. A., P. A. Durkee, H. H. Jonsson, K. Nielsen and D. S. Covert (2004). "Effects of aerosol and SST gradients on marine stratocumulus albedo." Geophysical Research Letters 31(6).

Heinze, C., V. Eyring, P. Friedlingstein, C. Jones, Y. Balkanski, W. Collins, T. Fichefet, S. Gao, A. Hall10 and D. J. E. S. D. Ivanova11 (2019). "Climate feedbacks in the Earth system and prospects for their evaluation." Earth System Dynamics.

Hempson, T. N., N. A. Graham, M. A. MacNeil, A. S. Hoey and S. K. Wilson (2018). "Ecosystem regime shifts disrupt trophic structure." Ecological applications 28(1): 191-200.

Hill, R. W., J. W. H. Dacey and D. A. Krupp (1995). "DIMETHYLSULFONIOPROPIONATE IN REEF CORALS." Bulletin of Marine Science 57(2): 489-494.

Hoegh-Guldberg, O. and J. F. Bruno (2010). "The Impact of Climate Change on the World's Marine Ecosystems." Science 328(5985): 1523-1528.

Hoegh-Guldberg, O., P. J. Mumby, A. J. Hooten, R. S. Steneck, P. Greenfield, E. Gomez, C. D. Harvell, P. F. Sale, A. J. Edwards and K. Caldeira (2007). "Coral reefs under rapid climate change and ocean acidification." science 318(5857): 1737-1742.

Hoegh-Guldberg, O., E. S. Poloczanska, W. Skirving and S. Dove (2017). "Coral Reef Ecosystems under Climate Change and Ocean Acidification." Frontiers in Marine Science 4(158).

Hopkins, F. E., T. G. Bell, M. Yang, D. J. Suggett and M. Steinke (2016). "Air exposure of coral is a significant source of dimethylsulfide (DMS) to the atmosphere." Scientific Reports 6.

Hrebien, V., E. Deschaseaux, W. Eickhoff, H. B. Swan and B. D. Eyre (2020). "Quantification of isoprene in coastal ecosystems by gas chromatography-mass spectrometry using cumulative headspace injections." Limnology and Oceanography: Methods: doi: 10.1002/lom1003.10363.

Peer) reviewing PDF | (2020:02:46057:2:1:NEW 26 Aug 2020) 
791

792

793

794

795

796

797

798

799

800

801

802

803

804

805

806

807

808

809

810

811

812

813

814

815

816

817

818

819

820

821

822

823

824

825

826

827

828

829

830

831

832

833

834

Huang, R.-J., Y. Zhang, C. Bozzetti, K.-F. Ho, J.-J. Cao, Y. Han, K. R. Daellenbach, J. G. Slowik, S. M. Platt, F. Canonaco, P. Zotter, R. Wolf, S. M. Pieber, E. A. Bruns, M. Crippa, G. Ciarelli, A. Piazzalunga, M. Schwikowski, G. Abbaszade, J. Schnelle-Kreis, R. Zimmermann, Z. An, S. Szidat, U. Baltensperger, I. E. Haddad and A. S. H. Prévôt (2014). "High secondary aerosol contribution to particulate pollution during haze events in China." Nature 514: 218.

Hughes, T. P., K. D. Anderson, S. R. Connolly, S. F. Heron, J. T. Kerry, J. M. Lough, A. H. Baird, J. K. Baum, M. L. Berumen and T. C. Bridge (2018a). "Spatial and temporal patterns of mass bleaching of corals in the Anthropocene." Science 359(6371): 80-83.

Hughes, T. P., M. L. Barnes, D. R. Bellwood, J. E. Cinner, G. S. Cumming, J. B. C. Jackson, J. Kleypas, I. A. van de Leemput, J. M. Lough, T. H. Morrison, S. R. Palumbi, E. H. van Nes and M. Scheffer (2017). "Coral reefs in the Anthropocene." Nature 546: 82.

Hughes, T. P., J. T. Kerry, A. H. Baird, S. R. Connolly, T. J. Chase, A. Dietzel, T. Hill, A. S. Hoey, M. O. Hoogenboom and M. Jacobson (2019). "Global warming impairs stock-recruitment dynamics of corals." Nature 568(7752): 387.

Hughes, T. P., J. T. Kerry, A. H. Baird, S. R. Connolly, A. Dietzel, C. M. Eakin, S. F. Heron, A. S. Hoey, M. O. Hoogenboom and G. Liu (2018b). "Global warming transforms coral reef assemblages." Nature 556(7702): 492.

Hughes, T. P., M. J. Rodrigues, D. R. Bellwood, D. Ceccarelli, O. Hoegh-Guldberg, L. McCook, N. Moltschaniwskyj, M. S. Pratchett, R. S. Steneck and B. J. C. B. Willis (2007). "Phase shifts, herbivory, and the resilience of coral reefs to climate change." Current Biology 17(4): 360-365.

Irvine, P. J., B. Kravitz, M. G. Lawrence, D. Gerten, C. Caminade, S. N. Gosling, E. J. Hendy, B. T. Kassie, W. D. Kissling and H. Muri (2017). "Towards a comprehensive climate impacts assessment of solar geoengineering." Earth's Future 5(1): 93-106.

Jackson, J. B. C. (2008). "Ecological extinction and evolution in the brave new ocean." Proceedings of the National Academy of Sciences 105(Supplement 1): 11458-11465.

Jackson, R., A. Gabric and R. Cropp (2018). "Effects of ocean warming and coral bleaching on aerosol emissions in the Great Barrier Reef, Australia." Scientific Reports 8(1): 14048.

Jackson, R. L., A. J. Gabric, M. T. Woodhouse, H. B. Swan, G. B. Jones, R. Cropp and E. S. M. Deschaseaux (2020). "Coral Reef Emissions of Atmospheric Dimethylsulfide and the Influence on Marine Aerosols in the Southern Great Barrier Reef, Australia." Journal of Geophysical Research: Atmospheres 125(7): e2019JD031837.

Jarníková, T. and P. D. Tortell (2016). "Towards a revised climatology of summertime dimethylsulfide concentrations and sea-air fluxes in the Southern Ocean." Environmental Chemistry 13(2): 364-378.

Peer) reviewing PDF | (2020:02:46057:2:1:NEW 26 Aug 2020) 
835

863

864

865

866

867
Jones, G., M. Curran, A. Broadbent, S. King, E. Fischer and R. Jones (2007). "Factors affecting the cycling of dimethylsulfide and dimethylsulfoniopropionate in coral reef waters of the Great Barrier Reef." Environmental Chemistry 4(5): 310-322.

Jones, G., M. Curran, E. Deschaseaux, Y. Omori, H. Tanimoto, H. Swan, B. Eyre, J. Ivey, E. McParland and A. Gabric (2018a). "The flux and emission of dimethylsulfide from the Great Barrier Reef region and potential influence on the climate of NE Australia." Journal of Geophysical Research: Atmospheres 123(24): 13,835-813,856.

Jones, G., M. Curran, E. Deschaseaux, Y. Omori, H. Tanimoto, H. Swan, B. Eyre, J. Ivey, E. McParland, A. Gabric and R. Cropp (2018b). "The Flux and Emission of Dimethylsulfide From the Great Barrier Reef Region and Potential Influence on the Climate of NE Australia." Journal of Geophysical Research: Atmospheres 123(24): 13,835-813,856.

Jones, G., M. Curran, H. Swan and E. Deschaseaux (2017). "Dimethylsulfide and Coral Bleaching: Links to Solar Radiation, Low Level Cloud and the Regulation of Seawater Temperatures and Climate in the Great Barrier Reef." American Journal of Climate Change 6(02): 328.

Jones, G. and S. King (2015). "Dimethylsulphoniopropionate (DMSP) as an indicator of bleaching tolerance in scleractinian corals." Journal of Marine Science and Engineering 3(2): 444-465.

Jones, G. B. (2015). The Reef Sulphur Cycle: Influence on Climate and Ecosystem Services. Ethnobiology of Corals and Coral Reefs. N. E. Narchi and L. L. Price: 27-57.

Jones, G. B., M. A. Curran and A. D. Broadbent (1994). Dimethylsulphide in the South Pacific. Recent Advances in Marine Science and Technology '94. O. Bellwood, H. Choat and N. Saxena, Pacon International and James Cook University.: 183-194.

Jones, G. B., E. Fischer, E. S. M. Deschaseaux and P. L. Harrison (2014). "The effect of coral bleaching on the cellular concentration of dimethylsulphoniopropionate in reef corals." Journal of Experimental Marine Biology and Ecology 460: 19-31.

Jones, G. B. and A. J. Trevena (2005). "The influence of coral reefs on atmospheric dimethylsulphide over the Great Barrier Reef, Coral Sea, Gulf of Papua and Solomon and Bismarck Seas." Marine and Freshwater Research 56(1): 85-93.

Jurriaans, S. and M. O. Hoogenboom (2020). "Seasonal acclimation of thermal performance in two species of reef-building corals." Marine Ecology Progress Series 635: 55-70.

Kennedy, E. V., A. Ordoñez and G. Diaz-Pulido (2018). "Coral bleaching in the southern inshore Great Barrier Reef: a case study from the Keppel Islands." Marine and Freshwater Research 69(1): 191-197. 
878 Kim, A.-H., S. S. Yum, H. Lee, D. Y. Chang and S. Shim (2018). "Polar Cooling Effect Due to Increase of Phytoplankton and Dimethyl-Sulfide Emission." Atmosphere 9(10): 384.

880

881

882

883

884

885

886

887

888

889

890

891

892

893

894

895

896

897

898

899

900

901

902

903

904

905

906

907

908

909

910

911

912

913

914

915

916

917

918

Kleypas, J. A., F. S. Castruccio, E. N. Curchitser and E. McLeod (2015). "The impact of ENSO on coral heat stress in the western equatorial Pacific." Global Change Biology 21(7): 2525-2539.

Kleypas, J. A., G. Danabasoglu and J. M. Lough (2008). "Potential role of the ocean thermostat in determining regional differences in coral reef bleaching events." Geophysical Research Letters 35(3).

Knowlton, N. (2001). "The future of coral reefs." Proceedings of the National Academy of Sciences 98(10): 5419-5425.

Knowlton, N. and J. B. Jackson (2008). "Shifting baselines, local impacts, and global change on coral reefs." PLoS biology 6(2): e54.

Korhonen, H., K. S. Carslaw, D. V. Spracklen, G. W. Mann and M. T. Woodhouse (2008). "Influence of oceanic dimethyl sulfide emissions on cloud condensation nuclei concentrations and seasonality over the remote Southern Hemisphere oceans: A global model study." Journal of Geophysical Research-

Atmospheres 113(D15).

Kruger, O. and H. Grassl (2011). "Southern Ocean phytoplankton increases cloud albedo and reduces precipitation." Geophysical Research Letters 38.

Kwiatkowski, L., P. Cox, P. R. Halloran, P. J. Mumby and A. J. Wiltshire (2015). "Coral bleaching under unconventional scenarios of climate warming and ocean acidification." Nature Climate Change 5(8): 777.

Lana, A., T. G. Bell, R. Simo, S. M. Vallina, J. Ballabrera-Poy, A. J. Kettle, J. Dachs, L. Bopp, E. S. Saltzman, J. Stefels, J. E. Johnson and P. S. Liss (2011). "An updated climatology of surface dimethlysulfide concentrations and emission fluxes in the global ocean." Global Biogeochemical Cycles 25.

Lana, A., R. Simó, S. M. Vallina and J. Dachs (2012). "Potential for a biogenic influence on cloud microphysics over the ocean: a correlation study with satellite-derived data." Atmos. Chem. Phys. 12(17): 7977-7993.

Langmann, B., B. Duncan, C. Textor, J. Trentmann and G. R. van der Werf (2009). "Vegetation fire emissions and their impact on air pollution and climate." Atmospheric Environment 43(1): 107-116.

Latham, J., J. Kleypas, R. Hauser, B. Parkes and A. Gadian (2013). "Can marine cloud brightening reduce coral bleaching?" Atmospheric Science Letters 14(4): 214-219.

Peer) reviewing PDF | (2020:02:46057:2:1:NEW 26 Aug 2020) 
919 Leck, C. and E. K. Bigg (2005). "Biogenic particles in the surface microlayer and overlaying atmosphere 920 in the central Arctic Ocean during summer." Tellus Series B-Chemical and Physical Meteorology 57(4):

$921305-316$.

922

923

924

925

926

927

928

929

930

931

932

933

934

935

936

937

938

939

940

941

942

943

944

945

946

947

948

949

950

951

952

953

954

955

956

957

958

959

960
Leck, C. and E. K. Bigg (2008). "Comparison of sources and nature of the tropical aerosol with the summer high Arctic aerosol." Tellus Series B-Chemical and Physical Meteorology 60(1): 118-126.

Lesser, M., W. Stochaj, D. Tapley and J. Shick (1990). "Bleaching in coral reef anthozoans: effects of irradiance, ultraviolet radiation, and temperature on the activities of protective enzymes against active oxygen." Coral Reefs 8(4): 225-232.

Lesser, M. P. and J. H. Farrell (2004). "Exposure to solar radiation increases damage to both host tissues and algal symbionts of corals during thermal stress." Coral Reefs 23(3): 367-377.

Liss, P. S., W. J. Broadgate, A. D. Hatton, R. H. Little, G. Malin, N. C. McArdle, P. D. Nightingale and S. M. Turner (2000). Biological Production of Trace Gases in Surface Sea Water and their Emission to the Atmosphere. Exchange and Transport of Air Pollutants over Complex Terrain and the Sea. S. Larsen, F. Fiedler and P. Borrell, Springer Berlin Heidelberg. 9: 139-144.

Liu, C.-Y., G.-B. Xu, X. Deng, H.-H. Zhang, T. Liu and G.-P. Yang (2020). "Changes in concentrations of biogenic sulfur compounds in coastal waters off Qingdao, China during an Ulva prolifera bloom." Marine Pollution Bulletin 152: 110940.

Lough, J. M. (2000). "1997-98: Unprecedented thermal stress to coral reefs?" Geophysical Research Letters 27(23): 3901-3904.

Lough, J. M. (2008). "Shifting climate zones for Australia's tropical marine ecosystems." Geophysical Research Letters 35(14).

Mahmood, R., K. v. Salzen, A.-L. Norman, M. Galí, M. J. A. C. Levasseur and Physics (2019). "Sensitivity of Arctic sulfate aerosol and clouds to changes in future surface seawater dimethylsulfide concentrations." Atmospheric Chemistry and Physics

19(9): 6419-6435.

Mallet, M., L. Cravigan, B. Miljevic, P. Vaattovaara, E. Deschaseaux, H. Swan, G. Jones and Z. Ristovski (2016). "Sea spray aerosol in the Great Barrier Reef and the presence of nonvolatile organics." Journal of Geophysical Research: Atmospheres 121(12): 7088-7099.

Masiri, I., M. Nunez and E. Weller (2008). "A 10-year climatology of solar radiation for the Great Barrier Reef: implications for recent mass coral bleaching events." International Journal of Remote Sensing 29(15): 4443-4462.

Peer) reviewing PDF | (2020:02:46057:2:1:NEW 26 Aug 2020) 
961 McCook, G. D.-P. L. J. (2002). "The fate of bleached corals: patterns and dynamics of algal recruitment." 962 Marine Ecology Progress Series 232: 115-128.

963

964

965

966

967

968

969

970

971

972

973

974

975

976

977

978

979

980

981

982

983

984

985

986

987

988

989

990

991

992

993

994

995

996

997

998

999

1000

1001

1002

1003

McCoy, D. T., S. M. Burrows, R. Wood, D. P. Grosvenor, S. M. Elliott, P.-L. Ma, P. J. Rasch and D. L. Hartmann (2015). Natural aerosols explain seasonal and spatial patterns of Southern Ocean cloud albedo.

McGowan, H., A. Sturman, M. Saunders, A. Theobald and A. Wiebe (2019). "Insights From a Decade of Research on Coral Reef-Atmosphere Energetics." Journal of Geophysical Research: Atmospheres 124(8): 4269-4282.

McGowan, H. and A. Theobald (2017). "ENSO weather and coral bleaching on the Great Barrier Reef, Australia." Geophysical Research Letters 44(20): 10,601-610,607.

McNeill, V. F. (2017). "Atmospheric Aerosols: Clouds, Chemistry, and Climate." Annual Review of Chemical and Biomolecular Engineering 8(1): 427-444.

Menzo, Z. M., S. Elliott, C. A. Hartin, F. M. Hoffman and S. Wang (2018). "Climate Change Impacts on Natural Sulfur Production: Ocean Acidification and Community Shifts." Atmosphere 9(5): 167.

Moberg, F. and C. Folke (1999). "Ecological goods and services of coral reef ecosystems." Ecological Economics 29(2): 215-233.

Modini, R. L., A. A. Frossard, L. Ahlm, L. M. Russell, C. E. Corrigan, G. C. Roberts, L. N. Hawkins, J. C. Schroder, A. K. Bertram, R. Zhao, A. K. Y. Lee, J. P. D. Abbatt, J. Lin, A. Nenes, Z. Wang, A. Wonaschütz, A. Sorooshian, K. J. Noone, H. Jonsson, J. H. Seinfeld, D. Toom-Sauntry, A. M. Macdonald and W. R. Leaitch (2015). "Primary marine aerosol-cloud interactions off the coast of California." Journal of Geophysical Research: Atmospheres 120(9): 4282-4303.

Modini, R. L., Z. D. Ristovski, G. R. Johnson, C. He, N. Surawski, L. Morawska, T. Suni and M. Kulmala (2009). "New particle formation and growth at a remote, sub-tropical coastal location." Atmospheric Chemistry and Physics 9(19): 7607-7621.

Mumby, P. J., R. M. C. John, J. E. Alasdair, A. Serge and J. Jean (2001). "Cloudy weather may have saved Society Island reef corals during the 1998 ENSO event." Marine Ecology Progress Series 222: 209216.

O'Dowd, C. D., J. L. Jimenez, R. Bahreini, R. C. Flagan, J. H. Seinfeld, K. Hämeri, L. Pirjola, M. Kulmala, S. G. Jennings and T. Hoffmann (2002). "Marine aerosol formation from biogenic iodine emissions." Nature 417(6889): 632-636.

Oliver, E., M. Donat, M. Burrows, P. Moore, D. Smale, L. Alexander, J. Benthuysen, M. Feng, A. Gupta and A. Hobday (2018). Longer and more frequent marine heatwaves over the past century, Nat.

Commun., 9, 1324.

Peer] reviewing PDF | (2020:02:46057:2:1:NEW 26 Aug 2020) 
1004

1005

1006

1007

1008

1009

1010

1011

1012

1013

1014

1015

1016

1017

1018

1019

1020

1021

1022

1023

1024

1025

1026

1027

1028

1029

1030

1031

1032

1033

1034

1035

1036

1037

1038

1039

1040

1041

1042

1043

1044

1045

1046

1047

Orellana, M. V., P. A. Matrai, C. Leck, C. D. Rauschenberg, A. M. Lee and E. Coz (2011). "Marine microgels as a source of cloud condensation nuclei in the high Arctic." Proceedings of the National Academy of Sciences of the United States of America 108(33): 13612-13617.

Pandolfi, J. M., R. H. Bradbury, E. Sala, T. P. Hughes, K. A. Bjorndal, R. G. Cooke, D. McArdle, L. McClenachan, M. J. H. Newman, G. Paredes, R. R. Warner and J. B. C. Jackson (2003). "Global

Trajectories of the Long-Term Decline of Coral Reef Ecosystems." Science 301(5635): 955-958.

Pincus, R. and M. B. Baker (1994). "Effect of precipitation on the albedo susceptibility of clouds in the marine boundary layer." Nature 372(6503): 250-252.

Qu, B., A. J. Gabric, M. Zeng and Z. Lu (2015). "Dimethylsulfide model calibration in the Barents Sea using a genetic algorithm and neural network." Environmental Chemistry.

Raina, J.-B., E. Dinsdale, B. Willis and D. Bourne (2010). "Do organic sulphur compounds DMSP and DMS drive coral microbial associations?" Trends in microbiology 18: 101-108.

Raina, J. B., D. M. Tapiolas, S. Foret, A. Lutz, D. Abrego, J. Ceh, F. O. Seneca, P. L. Clode, D. G. Bourne, B. L. Willis and C. A. Motti (2013). "DMSP biosynthesis by an animal and its role in coral thermal stress response." Nature 502(7473): 677-+.

Ramanathan, V. and W. Collins (1991). "Thermodynamic regulation of ocean warming by cirrus clouds deduced from observations of the 1987 El Nino." Nature 351(6321): 27.

Samset, B. H., M. Sand, C. J. Smith, S. E. Bauer, P. M. Forster, J. S. Fuglestvedt, S. Osprey and C.-F. Schleussner (2018). "Climate Impacts From a Removal of Anthropogenic Aerosol Emissions."

Geophysical Research Letters 45(2): 1020-1029.

Sanchez, K. J., C.-L. Chen, L. M. Russell, R. Betha, J. Liu, D. J. Price, P. Massoli, L. D. Ziemba, E. C. Crosbie, R. H. Moore, M. Müller, S. A. Schiller, A. Wisthaler, A. K. Y. Lee, P. K. Quinn, T. S. Bates, J. Porter, T. G. Bell, E. S. Saltzman, R. D. Vaillancourt and M. J. Behrenfeld (2018). "Substantial Seasonal Contribution of Observed Biogenic Sulfate Particles to Cloud Condensation Nuclei." Scientific Reports 8(1): 3235 .

Schmitt, R. J., S. J. Holbrook, S. L. Davis, A. J. Brooks and T. C. Adam (2019). "Experimental support for alternative attractors on coral reefs." Proceedings of the National Academy of Sciences 116(10): 43724381.

Schneider, T., J. Teixeira, C. S. Bretherton, F. Brient, K. G. Pressel, C. Schär and A. P. Siebesma (2017). "Climate goals and computing the future of clouds." Nature Climate Change 7(1): 3-5.

Seinfeld, J. H., C. Bretherton, K. S. Carslaw, H. Coe, P. J. DeMott, E. J. Dunlea, G. Feingold, S. Ghan, A. B. Guenther, R. Kahn, I. Kraucunas, S. M. Kreidenweis, M. J. Molina, A. Nenes, J. E. Penner, K. A.

Peer] reviewing PDF | (2020:02:46057:2:1:NEW 26 Aug 2020) 
1048 Prather, V. Ramanathan, V. Ramaswamy, P. J. Rasch, A. R. Ravishankara, D. Rosenfeld, G. Stephens and 1049 R. Wood (2016). "Improving our fundamental understanding of the role of aerosol-cloud interactions in

1050

1051

1052

1053

1054

1055

1056

1057

1058

1059

1060

1061

1062

1063

1064

1065

1066

1067

1068

1069

1070

1071

1072

1073

1074

1075

1076

1077

1078

1079

1080

1081

1082

1083

1084

1085

1086

1087

1088

1089

1090

the climate system." Proceedings of the National Academy of Sciences 113(21): 5781-5790.

Simó, R. (2001). "Production of atmospheric sulfur by oceanic plankton: biogeochemical, ecological and evolutionary links." Trends in Ecology \& Evolution 16: 287-294

Simpkins, G. (2018). "Aerosol-cloud interactions." Nature Climate Change 8(6): 457-457.

Six, K. D., S. Kloster, T. Ilyina, S. D. Archer, K. Zhang and E. Maier-Reimer (2013a). "Global warming amplified by reduced sulphur fluxes as a result of ocean acidification." Nature Clim. Change 3(11): 975978.

Six, K. D., S. Kloster, T. Ilyina, S. D. Archer, K. Zhang and E. Maier-Reimer (2013b). "Global warming amplified by reduced sulphur fluxes as a result of ocean acidification." Nature Climate Change 3(11): 975-978.

Steinke, M., P. Brading, P. Kerrison, M. E. Warner and D. J. Suggett (2011). "CONCENTRATIONS OF DIMETHYLSULFONIOPROPIONATE AND DIMETHYL SULFIDE ARE STRAIN-SPECIFIC IN SYMBIOTIC DINOFLAGELLATES (SYMBIODINIUM SP., DINOPHYCEAE) 1." Journal of phycology 47(4): 775-783.

Stephens, G. L. (2005). "Cloud Feedbacks in the Climate System: A Critical Review." Journal of Climate 18(2): 237-273.

Stoeckl, N., C. C. Hicks, M. Mills, K. Fabricius, M. Esparon, F. Kroon, K. Kaur and R. Costanza (2011). "The economic value of ecosystem services in the Great Barrier Reef: our state of knowledge." Annals of the New York Academy of Sciences 1219(1): 113-133.

Sunda, W., D. J. Kieber, R. P. Kiene and S. Huntsman (2002). "An antioxidant function for DMSP and DMS in marine algae." Nature 418(6895): 317-320.

Swan, H. B., R. W. Crough, P. Vaattovaara, G. B. Jones, E. S. M. Deschaseaux, B. D. Eyre, B. Miljevic and Z. D. Ristovski (2016). "Dimethyl sulfide and other biogenic volatile organic compound emissions from branching coral and reef seawater: potential sources of secondary aerosol over the Great Barrier Reef." Journal of Atmospheric Chemistry 73(3): 303-328.

Swan, H. B., G. B. Jones, E. S. Deschaseaux and B. D. Eyre (2017). "Coral reef origins of atmospheric dimethylsulfide at Heron Island, southern Great Barrier Reef, Australia." Biogeosciences Discussion.

Thompson, A., P. Costello, J. Davidson, M. Logan, B. Schaffelke, S. Uthicke and M. Takahashi (2011). "Reef rescue marine monitoring program." Report of AIMS Activities-Inshore coral reef monitoring: 127.

Peer] reviewing PDF | (2020:02:46057:2:1:NEW 26 Aug 2020) 
1091

1092

1093

1094

1095

1096

1097

1098

1099

1100

1101

1102

1103

1104

1105

1106

1107

1108

1109

1110

1111

1112

1113

1114

1115

1116

1117

1118

1119

1120

1121

1122

1123

1124

1125

1126

1127

1128

1129

1130

1131

1132

1133

1134

Thompson, A., P. Costello, J. Davidson, B. Schaffelke, S. Uthicke and M. Liddy (2013). "Reef Rescue Marine Monitoring Program: Report of AIMS Activities: inshore coral reef monitoring 2012. Report for Great Barrier Reef Marine Park Authority."

Torda, G., J. M. Donelson, M. Aranda, D. J. Barshis, L. Bay, M. L. Berumen, D. G. Bourne, N. Cantin, S. Foret and M. Matz (2017). "Rapid adaptive responses to climate change in corals." Nature Climate Change 7(9): 627-636.

Torraco, R. J. (2005). "Writing Integrative Literature Reviews: Guidelines and Examples." Human Resource Development Review 4(3): 356-367.

Torraco, R. J. (2016). "Writing Integrative Literature Reviews:Using the Past and Present to Explore the Future." Human Resource Development Review 15(4): 404-428.

Twomey, S. (1977). "The influence of pollution on the shortwave albedo of clouds." J. Atmos. Sci. 34: $1149-1152$.

Van Alstyne, K. L. and M. P. Puglisi (2007). "DMSP in marine macroalgae and macroinvertebrates: distribution, function, and ecological impacts." Aquatic Sciences 69(3): 394-402.

van der Zande, R. M., M. Achlatis, D. Bender-Champ, A. Kubicek, S. Dove and O. Hoegh-Guldberg (2020). "Paradise lost: End-of-century warming and acidification under business-as-usual emissions have severe consequences for symbiotic corals." Global Change Biology 26(4): 2203-2219.

van Oppen, M. J., J. K. Oliver, H. M. Putnam and R. D. Gates (2015). "Building coral reef resilience through assisted evolution." Proceedings of the National Academy of Sciences 112(8): 2307-2313.

Vergara-Temprado, J., A. K. Miltenberger, K. Furtado, D. P. Grosvenor, B. J. Shipway, A. A. Hill, J. M. Wilkinson, P. R. Field, B. J. Murray and K. S. Carslaw (2018). "Strong control of Southern Ocean cloud reflectivity by ice-nucleating particles." Proceedings of the National Academy of Sciences 115(11): $2687-$ 2692.

Walker, B., C. S. Holling, S. Carpenter and A. Kinzig (2004). "Resilience, adaptability and transformability in social-ecological systems." Ecology and society 9(2).

Webb, A. L., M. A. van Leeuwe, D. den Os, M. P. Meredith, H. J. Venables and J. Stefels (2019).

"Extreme spikes in DMS flux double estimates of biogenic sulfur export from the Antarctic coastal zone to the atmosphere." Scientific Reports 9(1): 2233.

Wingenter, O. W., K. B. Haase, M. Zeigler, D. R. Blake, F. S. Rowland, B. C. Sive, A. Paulino, R. Thyrhaug, A. Larsen, K. Schulz, M. Meyerhöfer and U. Riebesell (2007). "Unexpected consequences of increasing $\mathrm{CO} 2$ and ocean acidity on marine production of DMS and $\mathrm{CH} 2 \mathrm{ClI}$ : Potential climate impacts." Geophysical Research Letters 34(5).

Peer) reviewing PDF | (2020:02:46057:2:1:NEW 26 Aug 2020) 
1135

1136

1137

1138

1139

1140

1141

1142

1143

1144

1145

1146

1147

1148
Yakovleva, I. M., A. H. Baird, H. H. Yamamoto, R. Bhagooli, M. Nonaka and M. Hidaka (2009). "Algal symbionts increase oxidative damage and death in coral larvae at high temperatures." Marine Ecology Progress Series 378: 105-112.

Zhang, Z., A. Jones and M. J. C. Crabbe (2018). "Impacts of stratospheric aerosol geoengineering strategy on Caribbean coral reefs." International Journal of Climate Change Strategies and Management 10(4): 523-532.

Zhao, B., J. H. Jiang, Y. Gu, D. Diner, J. Worden, K.-N. Liou, H. Su, J. Xing, M. Garay and L. Huang (2017). "Decadal-scale trends in regional aerosol particle properties and their linkage to emission changes." Environmental Research Letters 12(5): 054021. 


\section{Table $\mathbf{1}$ (on next page)}

Range of atmospheric dimethylsulfide (DMS $)$ concentrations during field surveys of various ocean regions. 
1 Table 1. Range of atmospheric dimethylsulfide $\left(\mathrm{DMS}_{\mathrm{a}}\right)$ concentrations during field surveys of 2 various ocean regions.

3

\begin{tabular}{|c|c|c|}
\hline Region & $\mathrm{DMS}_{\mathrm{a}}\left(\mathrm{nmol} \mathrm{m}{ }^{-3}\right)$ & Reference(s) \\
\hline $\begin{array}{l}\text { Great } \quad \text { Barrier } \quad \text { Reef, } \\
\text { Australia* }\end{array}$ & $0.1-45.9$ & $\begin{array}{l}\text { Broadbent \& Jones, 2006; Jones \& } \\
\text { Trevena, 2005; Jones et al., 2007; Swan } \\
\text { et al., 2016, } 2017\end{array}$ \\
\hline North Coral Sea* & $0.3-6.9$ & Jones \& Trevena (2005) \\
\hline Gulf of Papua* & $0.5-2.9$ & Jones \& Trevena (200)5 \\
\hline Bismarck Sea* & $1-5.3$ & Jones \& Trevena (2005) \\
\hline Solomon Sea* & $1.2-5.3$ & Jones \& Trevena (2005) \\
\hline Bahamas* & $0.08-10.8$ & Andreae et al., 1985 \\
\hline Tropical East Pacific Ocean ${ }^{+}$ & $1.1-6.7$ & Andreae et al., 1985 \\
\hline Indian Ocean ${ }^{+}$ & $1.3-11.3$ & $\begin{array}{l}\text { Bandy et al. (1996); Conley et al. (2009); } \\
\text { Nguyen et al. (1990) }\end{array}$ \\
\hline North Pacific Ocean & $2.5-11.1$ & Aranami \& Tsunogai (2004) \\
\hline North Atlantic Ocean & $0.03-6.6$ & $\begin{array}{l}\text { Andreae et al. (1985); Andreae et al., } \\
(2003)\end{array}$ \\
\hline Arctic Ocean & $0.04-47.2$ & $\begin{array}{l}\text { Ferek et al.,(1995); Lunden et al., (2007); } \\
\text { Mungall et al., (2016); Park et al., (2013) }\end{array}$ \\
\hline Southern Ocean & $0.5-17.2$ & $\begin{array}{l}\text { Andreae et a., 1985; Berresheim et al., } \\
\text { 1990; Curran et al.(1998); Curran \& } \\
\text { Jones, (2000); Yang et al., (2011) }\end{array}$ \\
\hline Mediterranean & $0.3-8.9$ & Kouvarakis \& Mihalopoulos, (2002) \\
\hline Sargasso Sea & $0.02-16.3$ & Andreae et al. 1985 \\
\hline
\end{tabular}

4

$5 \quad{ }^{*}$ Coral reef dense regions.

6 Oceanic cruise tracks with intermittent coral reef regions. 


\section{Figure 1}

The cycling of reduced sulfur compounds in coral reef waters

Simplified overview of the cycling of reduced sulfur compounds in coral reef seawaters and their role in coral homeostasis. Corals upregulate dimethylsulfide (DMSP) biosynthesis and cleavage to dimethylsulfide (DMS) in response to physiological stress. DMS(P) scavenge reactive oxygen to mitigate oxidative damage, forming dimethyl sulfoxide (DMSO).

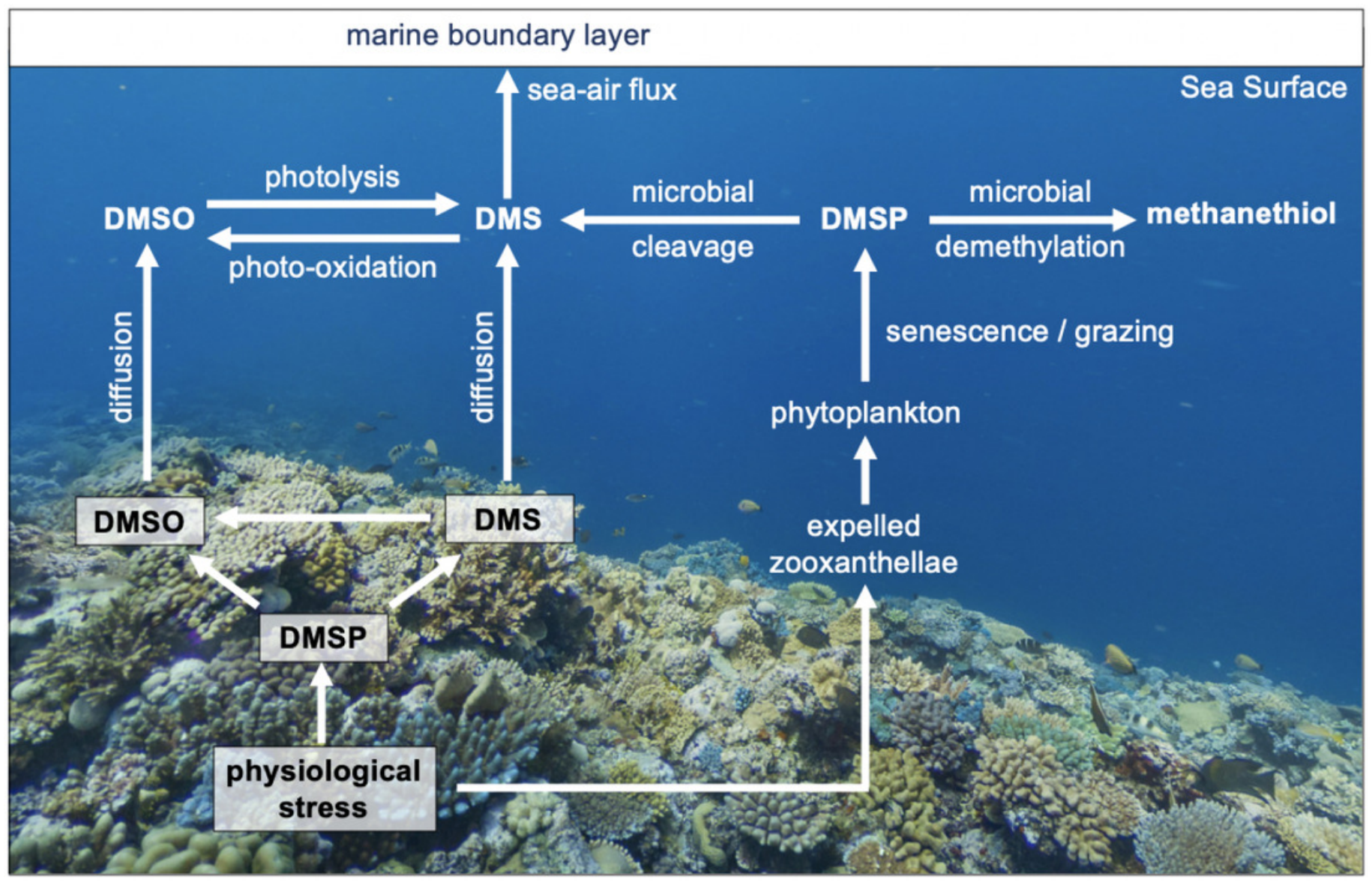




\section{Figure 2}

Influence of dimethylsulfide (DMS) emissions on marine atmosphere over coral reefs.

Summary of the influence of dimethylsulfide (DMS) emissions on marine aerosol, cloud condensation nuclei (CCN) and low-level clouds (LLC) over coral reefs. DMS is oxidized by hydroxyl radicals $(\mathrm{OH})$ to sulfur dioxide $\left(\mathrm{SO}_{2}\right)$ and secondarily to sulfuric acid $\left(\mathrm{H}_{2} \mathrm{SO}_{4}\right)$. DMSderived sulfates may condense onto pre-existing aerosols or undergo homogenous nucleation to form new non-sea salt sulfate $\left(\mathrm{nns}-\mathrm{SO}_{4}\right)$ particles, which can influence the local radiative balance.

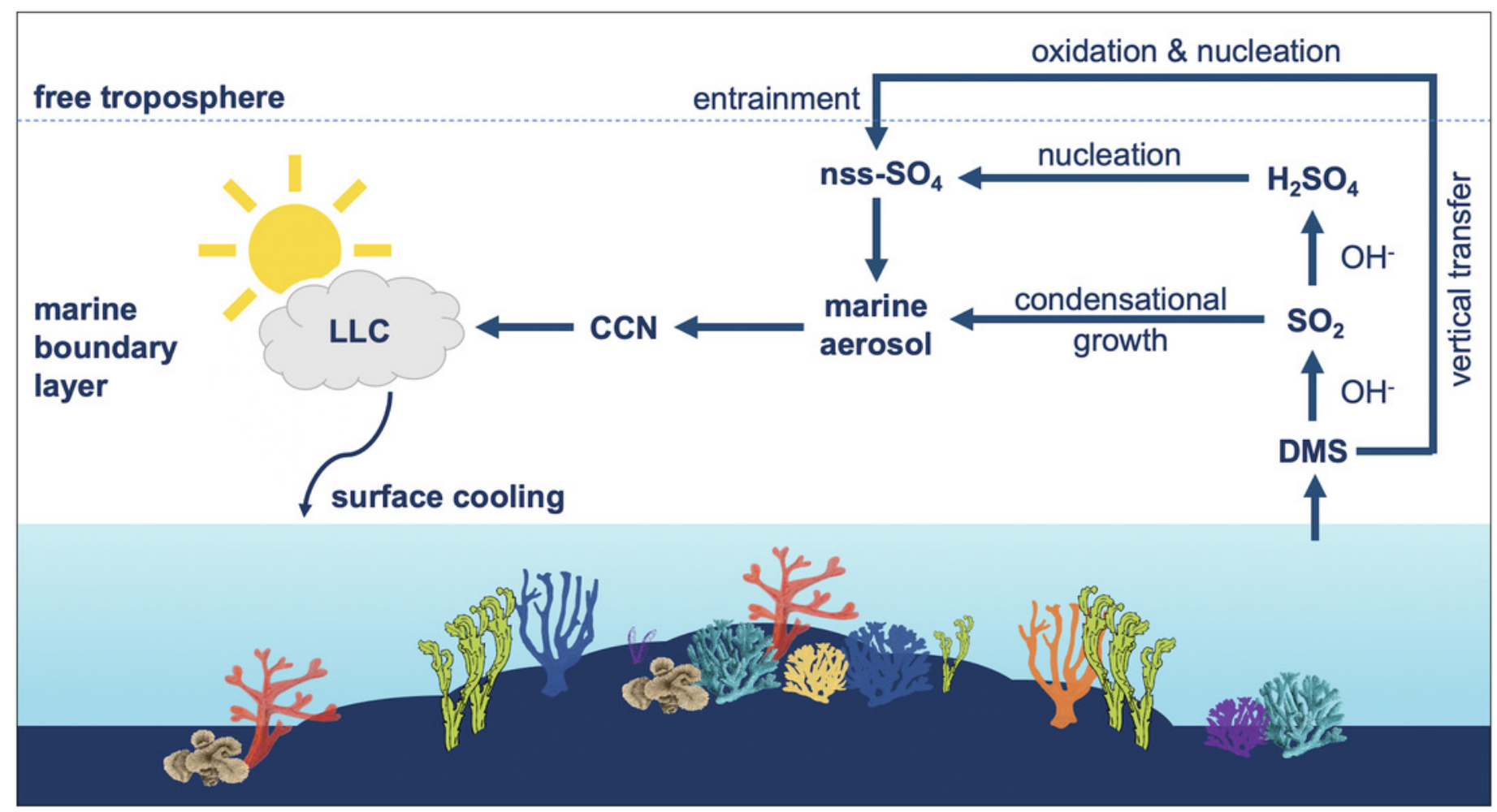


Figure 3

Diverse coral community at Norman Reef in the northern GBR.

Diverse coral community at Norman Reef in the northern Great Barrier Reef, Australia.

Source: Rebecca Jackson.

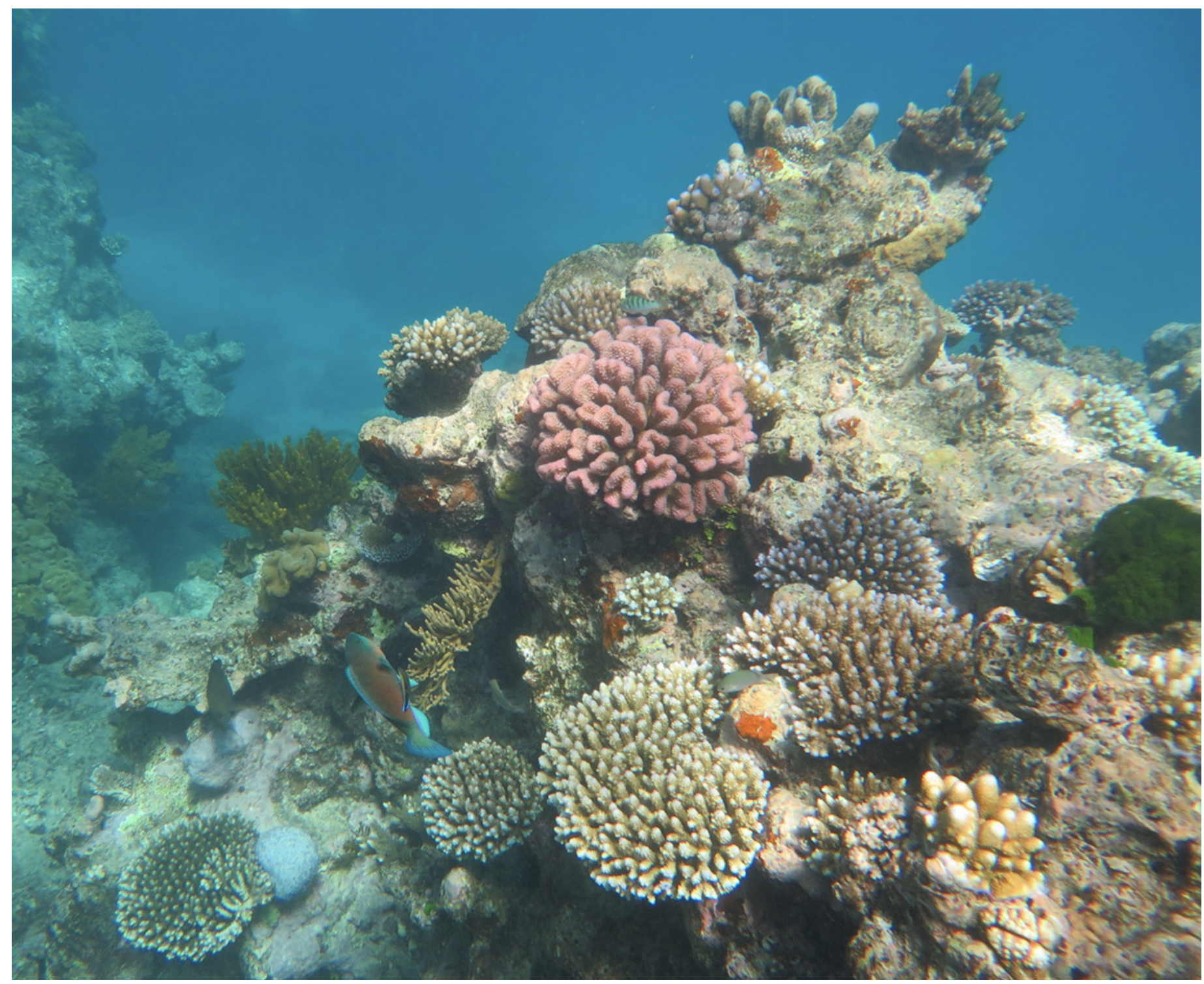

